\title{
Response of phytoplankton and bacterial biomassduring a wastewater effluent diversion into nearshore coastal waters
}

\author{
David A. Caron ${ }^{1 \mathrm{a}}$, Alyssa G. Gellene ${ }^{1}$, Jayme Smith ${ }^{1}$, Erica L. Seubert ${ }^{1}$, Victoria \\ Campbell $^{1}$, Gaurav S. Sukhatme ${ }^{2}$, Bridget Seegers ${ }^{1}$, Burton H. Jones ${ }^{1 *}$ Alle A.Y. Lie ${ }^{1}$, \\ Ramon Terrado ${ }^{1}$ \\ Meredith D.A. Howard ${ }^{3}$ \\ RaphaelM. Kudela ${ }^{4}$, Kendra Hayashi ${ }^{4}$ \\ John Ryan ${ }^{5}$, James Birch ${ }^{5}$, Elif Demir-Hilton ${ }^{5}$, Kevan Yamahara $^{5}$,Chris Scholin ${ }^{5}$ \\ Michael Mengel $^{6}$, George Robertson ${ }^{6}$
}

${ }^{1}$ Department of Biological Sciences, ${ }^{2}$ Department of Computer Science,University of Southern California, Los Angeles, CA 90089-0371

${ }^{3}$ Southern California Coastal Water Research Project, 3535 Harbor Blvd., Costa Mesa, CA 92626

${ }^{4}$ Ocean Sciences and Institute for Marine Sciences, University of California, Santa Cruz, 1156 High Street, Santa Cruz, CA 95064

${ }^{5}$ Monterey Bay Aquarium Research Institute, 7700 Sandholdt Rd, Moss Landing, CA 95039

${ }^{6}$ Orange County Sanitation District, 10844 Ellis Avenue, Fountain Valley, CA 92708

*Present address: King Abdullah University of Science and Technology, 4700 KAUST, 23955-6900, Thuwal, Kingdom of Saudi Arabia

${ }^{\mathrm{a} C}$ Corresponding author: Tel: 213-740-0203 Fax: 213-740-8123 Email: dcaron@usc.edu

Key words: Bacteria, phytoplankton, nutrients, coastal ecology, HABs, effluent. 


\begin{abstract}
A 3-week diversion of the Orange County Sanitation District effluent discharge into nearshore waters off Newport Beach, CA constituted a considerable injection of secondarily-treated effluent into the coastal ecosystem. Thelocation $\approx 1.6 \mathrm{~km}$ from shore, shallow water depth $(\approx 16 \mathrm{~m})$, volume and nutrient content of the discharge $\left(\approx 5.3 \times 10^{8}\right.$ liters day ${ }^{-1}$ of effluent with inorganic nitrogenconcentration $>2 \mathrm{mM}$ ) during the diversionraised concerns regarding the potential for stimulating phytoplankton blooms and, in particular, blooms of toxic species. Remarkably, phytoplankton standing stocksduring the event and shortly thereafter did not reachvalues associated even withminor blooms historically observedin the region (generally $<5 \mu \mathrm{g}^{-1}$ ), although shifts in community compositionwere observed. Diatom abundances increased early during the diversion, dinoflagellates, phototrophic picoplanktonic eukaryotes and other algae increased mid-diversion, and cyanobacteria (Synechococcus, Prochlorococcus) increased near the end of the diversion. Concentrations of domoic acid(a phycotoxin commonly present in the area) remained near or below detectionthroughout the diversion, and abundances of potentially-harmful algal species were unresponsive. Bacterial biomass increased during the diversion, and equaled or exceeded total phytoplankton biomass in most samples.Abundances of microbial grazerswere also elevatedduring the diversion. We speculate that nutrient uptake by the bacterial biomass, acting in concert with or a response to a negative effect of disinfection byproducts associated with chlorination on phytoplankton physiology, played a significant role in muting the response of the phytoplankton to nutrients released in the effluent.
\end{abstract}




\section{Introduction}

Coastal ecosystems along the eastern boundaries of oceanic gyres are highly dynamic environments that support robust biological communities and important fisheries. The hydrography that drives the major biological processes of these regions has been wellcharacterized on a global scale(Carr, 2001; Chavez and Messié, 2009), and many regional studies have provided details pertinent to the coastlines of specific geographical areas. The Southern California Bight (SCB) extends for approximately $700 \mathrm{~km}$ along a portion of the west coast of North America from Point Conception, California, USA to Cabo Colnett, Mexico. Numerous studies spanning several decades have investigated the oceanographic featurescontrolling primary production and food web structure of this coastal ecosystem(Cullen and Eppley, 1981; Hickey, 1992; Jones et al., 2002; Checkley and Barth, 2009; Kim et al., 2009; Nezlin et al., 2012). These studies have affirmed that upwelling events are important regional, seasonal events resulting in the injection of major nutrients (nitrogen, phosphorus) into surface waters that in turn supportpredominantly spring blooms of phytoplankton.

Studies in recent years, however, have also begun to demonstratethe increasing importanceof other processes as important contributors of nutrients and promoters of algal blooms in nearshore waters of the SCB.Specifically, Howard et al. (2014)presented evidence that surface coastal waters borderinghighly urbanized regions of the SCB, such as the greater Los Angeles area,receive inputs of anthropogenic nutrients, in particular nutrients discharged from Publicly Owned Treatment Works (POTWs), that are roughly equivalentto the load of nutrients injectedby upwelling events annually. This assessment is supported by the study of Nezlin et al. (2012) who noted increasing numbers of phytoplankton blooms in the region duringthe period 1997-2007, and a spatial correlation between the location of phytoplankton 'hot spots' in the SCB and POTW discharge points. In highly urbanized subregions of the $\mathrm{SCB}$, it has been estimated that more than $90 \%$ of terrestrial nutrient flux is wastewater effluent from local POTWs, most of which is discharged directly into coastal waters via a relatively small number of outfall pipes (Lyon et al., 2006; Sengupta et al., 2013). 
The relative magnitude and nature of the effectof nutrientsdischargedby POTWs on nearshore plankton communities is largely uncharacterized but could be expected to affectphytoplankton production, standing stock, community composition and related parameters (e.g. water turbidity, sedimentation, nutrient cycling, food web dynamics and dissolved oxygen) if the effluent were introduced into lighted waters where phytoplankton could utilize them for growth. The designs of the discharge systems of these facilities have therefore attempted to minimize these effects through improved wastewater treatment (Stein and Cadien, 2009), and by locating effluent discharge points offshore, and at depths that might lessen the input of growth-stimulating nutrients to phytoplankton in the overlying waters. This has proven to be an effective strategy for routine operations of POTWs in the SCB, but the interruption of normal operating procedures for these facilities leaves them with little alternative other than discharging effluent close to shore in shallow water (Howard et al., Submitted).

The preferential stimulation ofharmful algal blooms (HABs) presents a particular concern for the discharge of large volumes of nutrient-rich effluent into shallow coastal ecosystems, as anthropogenic nutrients have been shown to be a factor in the increased frequency of these events (Anderson et al., 2002; Heisler et al., 2008). Shifts in the concentrations and forms of growth-limiting nutrients could affect the standing stock of phytoplankton, as well as the species composition of the phytoplankton community due to nutrient preferences among algal taxa(Litchman et al., 2006). Nitrogen is generally considered the element limiting phytoplankton growth in many coastal waters dominated by upwelling (Capone and Hutchins, 2013), and while nitrate is the dominant form of nitrogen made available via upwelling, ammonium is overwhelmingly the dominant form of nitrogen in secondarily-treated effluent typical of POTWs in the SCB. Differences among algae in their preferences for these nitrogen forms could dramatically alter competition between algal taxa in the receiving waters, particularly with respect to harmful bloom-forming species(Dortch and Conway, 1984; Dortch, 1990; Kudela and Cochlan, 2000a; Dugdale et al., 2007; Kudela et al., 2008; Collos and Harrison, 2014).

The SCB has experienced an increase in the number, frequency and severity oftoxic algal blooms in recent years. Massive discolorations of coastal waterresulting fromblooms of the relatively innocuous dinoflagellate,Lingulodinium polyedrum, have 
been reported along the coastline for many years(Holmes et al., 1967; Gregorio and Pieper, 2000; Kudela and Cochlan, 2000b), buttoxic blooms of diatom species within the genusPseudo-nitzschia have been documentedthroughout the last decade(Schnetzer et al., 2007; Schnetzer et al., 2013). Recent field studies have implicated a relationship betweenblooms of Pseudo-nitzschiaand upwelling eventsalong the continental shelf bordering the cities ofSan Pedro and Long Beach (Schnetzer et al., 2013; Seubert et al., 2013), but it has become clear that anthropogenic sources of nutrients may also play a rolein thefrequency and/or severity of these events(Howard et al., 2014). The San Pedro shelf is now recognized as a "hot spot" for outbreaks of domoic acid, resulting in marine animal mortality events attributed to that neurotoxin (Schnetzer et al., 2007; Schnetzer et al., 2013; Seubert et al., 2014). Other toxin-producing or noxious phytoplankton genera also occur along the coast of the SCB, and include raphidophyte and dinoflagellate species (Jessup et al., 2009; Caron et al., 2010; Garneau et al., 2011; Howard et al., 2012; Lewitus et al., 2012).

The Orange County Sanitation District (OCSD) conducted a planned diversion (September 11 to October 3, 2012) of its effluent dischargefrom its $8 \mathrm{~km}$ outfall pipe to a nearshore $(1.6 \mathrm{~km})$, shallower discharge pipe in order to make necessary repairs to the longer pipe (Howard et al., Submitted). This event provided a unique opportunity to investigate the response of a nearshore coastal ecosystem in the SCB to a significant release of anthropogenic nutrients. An array of instrumentation-based measurements provided contextual information whileshipboard water sampling wasconducted prior to, during, and following the diversion to evaluate the effect. The diversion resulted in the discharge of effluent containing dissolved inorganic nitrogen and other constituents at approximately 1000-fold higher concentration ( $>2 \mathrm{mM})$ than typical ambient concentrations in shallow water $(<15 \mathrm{~m}$ water depth) in the region(Howard et al., Submitted). This effluent was also highly disinfected with sodium hypochlorite (higher than normal dosage) due to the close proximity of release to the shoreline. The goal of this study was to document the response of the phytoplankton to nutrient loading on the San Pedro shelf in the vicinity of the cities of Newport Beach and Huntington Beach. Surprisingly, the overall increase in phytoplanktonbiomass during the 3-week diversion was minor, although shifts in taxonomic composition did occur. We speculate that the 
muted response of the phytoplankton may have been a combined effect of short-term deleterious effects of disinfection byproductsin the effluent on phytoplankton growth and physiology, combined with rapid uptake of nutrients by the bacterial assemblage.

\section{Methods and Materials}

\subsection{Study site and discharge pipe location}

The study was conducted in waters along the San Pedro continental shelf primarily near the border between the cities of Newport Beach and Huntington Beach (Fig. 1). An overview of the location of the nearshore discharge pipe of the OCSD, as well as the timing and magnitude of the diversion of effluent to that pipewithin the study site has been provided by Howard et al. (Submitted). Instrumentation as described below was positioned near the discharge site and provided measurements of physical, chemical and biological parameters prior to, during and following the diversion of effluent. These instruments included two ocean moorings and an Environmental Sample Processor equipped with multiple sensors andsample processing capabilities.

Three types of shipboard surveys (see below) were conducted to characterize the response of the natural plankton community within the study site and region to the effluent discharge. Water from these survey cruises was also used for experimental incubation studies (conducted ashore) to examine the response of the planktonic community tothe addition of diluted effluent (Seubert et al., Submitted).

\subsection{Ocean moorings}

Two instrumented ocean buoys were moored approximately $2 \mathrm{~km}$ north $\left(33^{\circ} 37.072^{\prime}\right.$ $\left.\mathrm{N}, 117^{\circ} 59.733^{\prime} \mathrm{W}\right)$ and $2 \mathrm{~km}$ south $\left(33^{\circ} 36.077^{\prime} \mathrm{N}, 117^{\circ} 57.414^{\prime} \mathrm{W}\right)$ of the nearshore outfall location (Fig. 1). Eachbuoywas equipped with a WETlabs Water Quality Monitor (WQM; WET Labs, Philomath, OR) and the northern buoy also carried a WETlabs Cycle Phosphate Sensor.Instruments were deployed at approximately $1 \mathrm{~m}$ depth. The WQMs were equipped to measure chlorophyll fluorescence, turbidity, dissolved oxygen, 
temperature, and conductivity (salinity) at a sample rate of $3 \mathrm{hr}^{-1}$, the Cycle Phosphate Sensor sampled at a rate of $1 \mathrm{hr}^{-1}$. All sensors andequipment were inspected, cleaned and calibrated prior to deployment per manufacturers' or organizational recommendations (see http://www.ocsd.com/).

\subsection{Environmental Sample Processor}

The Environmental Sample Processor (ESP) was employed to provide persistent monitoring of HAB species and environmental data (Scholin, 2013). Two ESP instruments were deployed sequentially at the same location between August 30 and October 16, with a changeover on September 26. The mooring was located in the vicinity of the outfall site $\left(33^{\circ} 35.81^{\prime} \mathrm{N}, 117^{\circ} 56.77^{\prime} \mathrm{W}\right.$; Fig. 1), and the ESP was located on the mooring at a depth of 6.0-7.5 m (depending on tide). The ESPs were deployed with a Conductivity, Temperature and Depth sensor (CTD) (Seabird SBE 16+ CTD, Bellevue, WA, USA), fluorometer (Turner Cyclops-7, Turner Designs, Sunnyvale, CA, USA) and transmissometer (WetLABS Cstar, WET Labs, Philomath, OR, USA).Sensors were calibrated prior to deployment according to manufacturers' specifications (WET Labs, Philomath, OR), and sensor drift was established from post-deployment recalibration. CTD data were recorded at 5 min intervals. In addition to sensor measurements, the instrumentwas equipped for whole-cell sandwich hybridization assays for the HAB species Alexandrium catenella, Heterosigma akashiwo, Pseudonitzschiaaustralis, Pseudo-nitzschiamultiseries and Pseudonitzschiamultiseries/pseudodelicatissima(Greenfield et al., 2008; Ryan et al., 2011; Ryan et al., 2014). Sample acquisition and processing for the latter assays were conducted onboard episodically prior to, during and following the effluent diversion event.

\subsection{Shipboard campaigns}

\subsubsection{Sensed and automated shipboard measurements}


Three types of shipboard surveys were conducted in conjunction with the diversion.'Plume-tracking cruises' were conducted aboard the M/V Nerissa (OCSD) on eight sampling dates (September 10, 11, 12, 18, 19, 25 and October 2, 9). The focus of these cruises was water quality and phytoplankton monitoring across a large number of stations on the San Pedro shelf in the immediate vicinity of the effluent discharge during the diversion (see explanation and color coding in Fig. 1). The specific subset of stations was adjusted for each cruise based on daily current predictions from the Regional Ocean Modeling System and drifter studies in order to best capture effluent-affected coastal water(Farrara et al., Submitted). The specific stations sampled on a given sampling dayconsisted of an up-coast subset of stations in the event that prevailing currents were predicted to carry the discharge plume in that direction, whilesampling stations consisted of a subset ofdown-coast stations if current predictions indicated down-coast movement of the plume (see specific stations occupied on each cruise in Supplemental Fig. S1). A set of stations in the proximity of the outfall was sampled on every cruise in order to capture conditions there.Three of the last four plume-tracking cruises were conducted using somewhat different station locations than the other cruises in order to characterize a slightly larger geographical area under the assumption that effluent impact might be more dispersed by these later dates (Fig. 1 and Supplemental Fig. S1E,G,H). A hydrocast was conducted at each station during these cruises to obtain vertical profiles of temperature, conductivity and chlorophyll fluorescencein the water column. The CTD was inspected and calibrated prior to each sampling survey per manufacturers' recommendations (see http://www.ocsd.com/), the fluorometer was returned to the manufacturer for calibration. Contours of sensed data were constructed using IGODS (IGODS, 2012). All salinity units were measured using the Practical Salinity Scale.

Response of the plankton community along an onshore-offshore transect linefrom the vicinity of the outfall seaward to the San Pedro shelf break along and beyond the outfall pipewas examined on five 'event cruises' (September 6, 12, 20, 26, October 17; see station coding in Fig. 1) aboard the R/V Yellowfin (Southern California Marine Institute) or the M/V Nerissa. Five stations were conducted on each cruise. A hydrocast was conducted at each station to obtain vertical profiles of temperature, conductivity and chlorophyll fluorescence. Hydrocasts aboard the vessels were conducted using a Sea- 
Bird SBE911plus CTD (SBE3plus temperature sensor; SBE4C conductivity sensor; SBE 43 oxygen sensor; SBE32 water sampling carousel;Sea-Bird Electronics, Bellevue, WA). The Nerissa was also equipped with a Wet Labs Wetstar fluorometer (Wet Labs, Philomath, OR), while the Yellowfin was equipped with a Wet Labs ECO-FLNTU(RT)D fluorometer. The CTD on the Yellowfin was newly acquired and calibrated by the manufacturer prior to delivery.

One 'regional cruise' was conducted on October 10, 2012 to examine the response of the plankton community over a larger geographical area than routinely carried out for the plume-tracking or event cruises (inset in Fig. 1). This cruise was conducted one week after the conclusion of the diversion and extended alongshore to the south of the effluent discharge point, in accordance with current models that predicted a net down-coast water movement from the study area. The cruise track then proceeded seaward, and then north towards the city of Newport Beach. Hydrocasts were conducted four times along each of the three legs of the cruise to obtain vertical profiles of temperature, conductivity, dissolved oxygen and chlorophyll fluorescence.

\subsubsection{Nutrients and planktonmeasurements from samples collected shipboard}

Water samples were collected at the surface (0-2 m) and at the depth of the subsurface chlorophyll maximum (Subsurface Chlorophyll Maximum, SCM, the latter detected using thevertical profile of chlorophyll fluorescence from the sensor package on the sampling rosette)ata subset of stations conducted as a part of the plume-tracking, event and regional cruises. Samples used toobtain counts of phytoplankton and microzooplankton $>10 \mu \mathrm{m}$ in size were preserved with formalin, identified and counted using an inverted microscopeafter settling in settling chambers according to procedures described previously (Seubert et al., 2013), and summed according to major taxon (limit

of detection $\approx 1 \mathrm{cell} \mathrm{ml}^{-1}$ ). Samples for counts of phototrophic picoplanktonic eukaryotes (eukaryotic algae $<10 \mu \mathrm{m}$ ), picoplanktonic cyanobacteria (Synechococcus and Prochlorococcus) and heterotrophic bacteria (bacteria+archaea) were collected, preserved with formalin, and stored frozen at $-80^{\circ} \mathrm{C}$ until analyzed by flow cytometry. Flow cytometry was conducted using a FACSCalibur flow cytometer (Becton Dickinson). 
Cyanobacteria and picoplanktonic eukaryotic algae were detected using autofluorescence of photosynthetic pigments and forward scatter, while bacterial abundances were determined using routine staining procedures and detection parameters(del Giorgio et al., 1996).Samples collected for nutrient analyses were obtained from $0.2 \mu \mathrm{m}$ filtrate of the same water samples used to obtain microbiological abundances, and processed for concentrations of nitrate + nitrite, ammonium and phosphate at the Analytical Laboratory at the Marine Sciences Institute at University of California, Santa Barbara.

Samples for thedetermination of extracted chlorophyll concentration and particulate domoic acidconcentration (pDA)were collected from the same samples on the plumetracking, event and regional cruises. Sample volumes of $100 \mathrm{ml}$ and $200 \mathrm{mlwere}$ filtered onto GF/F Whatman filters, respectively. Samples for the determination of chlorophyll $a$ were extracted in $100 \%$ acetone for $24 \mathrm{~h}$ at $-20{ }^{\circ} \mathrm{C}$ in the dark, and analyzed by fluorometry (Trilogy; Turner Designs Inc, Sunnyvale, CA, USA) using standard methods(Parsons et al., 1984).Domoic acid in particulate material collected on filters was extracted in $3 \mathrm{ml}$ of $10 \%$ methanol, sonicated for $30 \mathrm{~s}$, and centrifuged for $10 \mathrm{~min}$ at 4,000 rpm. The supernatant was analyzed using the Mercury Science Inc. DA EnzymeLinked ImmunoSorbent Assay (ELISA; Durham, NC) following the methods described in Seubert et al. (2013).The limit of detection for the assay was $0.02 \mu \mathrm{g} \mathrm{l}^{-1}$.

\subsubsection{Estimating phytoplankton and bacterial biomass in discrete samples.}

The carbon and nitrogen contents of the phytoplankton and bacterial assemblages were calculated from extracted chlorophyll values and cell abundances, respectively, in the discrete seawater samples in order to facilitate comparison of the relative importance of these biological compartments to each other or to the inorganic nitrogen pool. Phytoplankton carbon biomass was estimated from extracted chlorophyll values from each discrete sample assuming a carbon:chlorophyll $(\mathrm{C}: \mathrm{Chl})$ ratio of 25 . Literature values for the $\mathrm{C}: \mathrm{Chl}$ ratio vary by approximately one order of magnitude (Riemann et al., 1989), and a value of 25 is typical for coastal phytoplankton assemblages. The nitrogen content of the phytoplankton was then calculated using approximately Redfield Ratio proportions for carbon:nitrogen (C:N=7, atom:atom). A C:N ratio of 7 assumes 
phytoplankton in good physiological condition. Bacterial abundances were converted directly to carbon content assuming $20 \mathrm{fg} \mathrm{C}$ bacterium $^{-1}$ which is typical of coastal bacteria assemblages (Buitenhuis et al., 2012). Nitrogen content was estimated using a $\mathrm{C}: \mathrm{N}$ slightly lower than Redfield Ratio $(\mathrm{C}: \mathrm{N}=5)$, applicable for these nitrogen-rich cells (Fukuda et al., 1998).

\section{Results}

\subsection{Contextual information for the study site provided by shipboard instrument profiling and autonomous instrumentation}

Extensive chemical and physical data were collected on the three types of shipboard surveys conducted in the coastal region near and away from the end of the $1.6 \mathrm{~km}$ pipe, and from the moored instruments located up- and down-coast from the location of the outfall (Fig. 1). A large number of vertical profiles of temperature, salinity and chlorophyll fluorescence on eight dates spanning from pre- to post-diversion (Supplemental Figs. S1-S5) and continuous sensor recordings on the two buoys and the ESP (Figs. 2,3A,B,C)revealed spatial and temporal heterogeneity in those parameters, particularly at small scales.

Relatively warm surface watersfor the region and season, and overall low phytoplankton biomassvalues were observed from data collected during the plumetracking cruises (Supplemental Figs. S1-3). Temperaturestratification appeared weaker on some sampling dates during the diversion (e.g. Sept 18 and 25; Supplemental Fig. S2D, F) but no clear evidence of upwelling was apparent prior to or during the diversion. Total phytoplankton biomass as indicated by chlorophyll fluorescence from the sensors on the CTD rosettesacross all sampling stations and dates showed minor excursions, but values rarely reached $5 \mu \mathrm{g}$ chlorophyll $1^{-1}$ throughout the entire region prior to, during and immediately following the diversion (Supplemental Fig. S3). The highest chlorophyll concentrations observed during the plume-tracking cruises were located near the shelf break on October 2 (one day before the diversion ended) but chlorophyll values had returned to low values by October 9 (Supplemental Fig. S3G, H, respectively). 
Five event cruises conducted along an onshore-offshore transect line in the vicinity of the outfall prior to, during and following the diversion also revealed no notable response of the phytoplankton along the transect line which extended observations farther from shore than the plume-tracking cruises, out beyond the San Pedro shelf. Contour plots of sensed chlorophyll fluorescence during the event cruises showed no clear relationship of the surface or subsurface distribution of phytoplankton biomass to the diversion event(Supplemental Fig. S4; note scale is the same for Supplemental Fig. S3). A persistent subsurface maximum of chlorophyll (SubsurfaceChlorophyll Maximum; SCM) is a common feature of this region (Kim et al., 2013; Schnetzer et al., 2013). The SCM was present as a weak feature duringthis study, particularly at the offshore stations (Supplemental Fig. S4A,E). This finding was consistent with the general hydrography of the region in that water stratification offshore is typically less affected by on-shelf processes of wind and tidal mixing that lead to shoaling and mixing of the SCM on the shelf.

A regional cruise was conducted on October 10 to investigate the possibility that advection of the nutrient-rich plume, and subsequent utilization of those nutrients in the direction of the predominant southerly current (Farrara et al., submitted) might have stimulated phytoplankton growth away from the study site on or off the San Pedro shelf (Supplemental Fig. S5). Chlorophyll fluorescence was very low along the approximately $25 \mathrm{~km}$ cruise track south, and also seaward off the shelf, only one week after the 3-week diversion.

The moored buoys situated north and south of the outfall locationshowed similar overall patterns in measured parameters, although both buoysexhibited considerable short-term fluctuations of relatively small amplitudes for all sensed parameters (Fig. 2). These short-term fluctuations reflected a combination of tidal modulation, diel variations and plume-influenced impactson these parameters.Temperature at the depth of the sensor $(1 \mathrm{~m})$ fluctuated within a $2^{\circ} \mathrm{C}$ range prior to and during the diversion, and then decreased steadily for three weeks following the diversion (Fig. 2A). Salinity decreased slightly (average of approximately 0.1 ') during the diversion at both buoys presumably indicating dilution of effluent 1:100 to 1:1000with the water column near the discharge site (Fig. 2B). This degree of effluent dilution is consistent with predicted, initial dilution 
at the point of discharge (note black horizontal bar in Fig. 2B indicating timing of the diversion). The phosphate sensor on the northern buoy exhibited several brief increases to values $>0.6 \mu$ Mduring the diversion (Fig. 2D), in agreement with nutrient measurements made on discrete samples (data not presented). Chlorophyll fluorescence rarely exceeded $3 \mu \mathrm{g}^{-1}$ throughout the study period at either mooring location (Fig. 2C), and dissolved oxygen showed only a minor overall positive response (Fig. 2E).

Temperature, salinity and chlorophyll fluorescence recorded on the ESP (Fig. 3A-C) located in the vicinity of the outfall revealed considerable small-scale temporal variability, consistent with the buoy measurements and shipboard sensor measurements (Fig. 2, Supplemental Figs. S2-3). Salinity values on the ESP decreased 0.1-0.2' during the diversion, implying initial dilution of the effluent of 1:100 to 1:1000 in the water column near the discharge site.The chlorophyll sensor failed on the first ESP and the instrument was replaced near the end of the diversion. Chlorophyll fluorescence on the ESP revealed a brief increase in phytoplankton biomass near the end of the diversion, with one short-lived spike to $>15 \mu \mathrm{g}$ chlorophyll $1^{-1}$. This latter value was considerably greater than any other chlorophyll fluorescence valueobserved during the study and any of the chlorophyll values from extracted samples (see below). It may have been a result of a very small patch of elevated phytoplankton biomass or perhaps suspended macroalgal debrisat the depth of the sensor (6-7.5 m). Chlorophyll fluorescence measurements immediately following the diversion were modest.

\subsection{Nutrient and biological measurements on plume-affected, discrete water samples}

\subsubsection{Selecting plume-affected water samples}

A major goal of this study was to determine the impact of nutrients in the effluent plume on the biological community in the coastal ocean near the discharge. Due to the wide geographic region covered by the three shipboard surveys, some water samples collected during the surveys would not be expected to be substantively influenced by the effluent plume. Additionally, effluent from the $8 \mathrm{~km}$ pipe prior to or early during the diversion may have influencedsome stations not immediately in the vicinity of the $1.6 \mathrm{~km}$ 
outfall. Therefore, we attempted to identify those samplesamong the total sample set (175 discrete samples)that were at least partially affected by effluent dischargeby:(1) using salinity as a conservative tracer of the freshwater (effluent) discharge; (2) eliminating the deepest, coldest water samples in the datasetbecause phytoplankton in those samples might not have experienced sufficient light or time to utilize effluent nutrients.

The initial dataset of 175 samples was plotted on temperature-salinity (T-S) diagramswith samples identified by depth and nitrogen concentration of four constituents:ammonium, nitrogen contained in phytoplankton biomass (phytoplankton$\mathrm{N}$ ), nitrogen contained in bacterial biomass (bacterial-N) and the sum of those three values (ammonium- $\mathrm{N}+$ phytoplankton- $\mathrm{N}+$ bacterial- $\mathrm{N}$ ) in each sample as described in the Methods and Materials (Fig. 4). Phytoplanktonbiomass and bacterial biomass were converted to nitrogen in order to facilitate comparison between these biological assemblages and to the major inorganic nutrient nitrogen in the effluent (ammonium). Substantive ammonium concentrationswere considered indicative of recent plume impact.Ammonium was by far the dominant form of dissolved nitrogen in the effluent ( $>2 \mathrm{mM}$ ), and therefore should be the major form of inorganic nutrient in the diluted effluent unless biology had significantly reduced the inorganic nitrogen pool.

The resulting T-S plots of all discrete samples processed for these constituents revealed a small number of stations for which salinities were greater than all other samples, and a larger number of samples with temperatures $<16{ }^{\circ} \mathrm{C}$ and/or depths $>30 \mathrm{~m}$ (Fig. 4). Samples meeting these criteria (salinity $>33.50$ ', temperature $<16{ }^{\circ} \mathrm{C}$ or depth $>30 \mathrm{~m}$ ) were eliminated from further consideration for reasons noted above.

The remaining 108 'plume-affected' samples in the culled dataset revealed negative (albeit weak) correlations between ammonium-N, phytoplankton-N, bacterial-N, or total$\mathrm{N}$ and salinity, as would be expected if salinity is a good proxy for the influence of effluent (Fig. 5).A few very high concentrations of ammonium ( $>20 \mu \mathrm{M})$ were observed in samples collected in close proximity to thesurfacing discharge plume. The latterfinding is consistent with the expectation that it requires some amount of time for nutrients in freshly-diluted effluent to enter the biological community in the coastal ecosystem. Interestingly, extrapolation of the regression of total-N versus salinity(Fig. 
$5 \mathrm{~A})$ to salinity $=0$ (i.e. $\approx$ pure effluent) yielded nitrogen concentrations $\approx 0.7 \mathrm{mM}$ in the undiluted effluent, in approximate agreement with inorganic nitrogen concentration measured in the effluent.

\subsubsection{Phytoplankton biomass and community composition}

The phytoplankton community during the diversionresponded withshifts in major phytoplankton taxonomic group abundances but, overall,phytoplankton biomass did not achievevalues indicative of blooms in the region(Table 1; Fig. 6). Phytoplankton biomass as indicated by chlorophyll concentration in the discrete water samples increased several-fold by September 18 (Fig. 6A), and the overall average for samples collected during the diversion was nearly 4-fold higher than pre-diversion values (Table 1). However, chlorophyll values were low at the time of the pre-diversion sampling (average $=0.48 \mu \mathrm{g} \mathrm{l}^{-1}$ ) and therefore increases during the diversion only rarely and sporadically achieved values comparable to minor blooms previously observed along the coast in the region (Kim et al., 2009; Seubert et al., 2013).

Net population changes in major taxonomic groups of phytoplankton varied during the diversion. Diatom abundances exhibited a gradual increase from the beginning of the bloom, weremarkedhigher on September 20, followedby waning abundances through mid- and post-diversion (Fig. 6B). Diatoms remained the dominant phytoplankton $>10$ $\mu \mathrm{m}$ throughout the study.Pseudo-nitzschia species were regularly observed in the HAB arrays of the ESP situated near the outfall, as well as other potentially-toxic species of algae, but showed no clear trend related to the diversion(Fig. 3D).Domoic acid was analyzed in 214 samples collected during the cruises, but very low concentrations of domoic acid were observed in particulate material from samples collected only on three dates, with highest values observed on a single date in samples from the SCM (data not shown). These values $\left(\leq 0.05 \mu \mathrm{g} \mathrm{l^{-1 }}\right.$ in surface waters) were two orders of magnitude lower than maximal values previously observed in the plankton of the region (Schnetzer et al., 2007; Stauffer et al., 2012; Schnetzer et al., 2013).

Dinoflagellate abundances were higher only on a single, mid-diversion sampling day (Fig. 6C).One potentially harmful dinoflagellate (Alexandrium catenatum) was observed 
only sporadically in the HAB arrays of the ESP. Dinoflagellates of the genus Dinophysis were observed in samples collected during the diversion as part of the Southern California Coastal Ocean Observing System HABweekly sampling program (http://www.sccoos.org/data/habs/). Samples analyzed by ELISA for okadaic acid, a toxin produced by Dinophysis species and the cause of Diarrhetic Shellfish Poisoning in humans, were positive during the diversion for the first time since that weekly time series began in 2008 (Seubert et al., unpublished data). 'Other' microplanktonic phytoplankton groups (Fig. 6D) contributed only a minor component to total phytoplankton, and changes in their abundances showed no detectable response to the event, including one potentially-toxicraphidophyte, Heterosigma akashiwo (Fig. 3D, 6D; note different scale in Fig. $6 \mathrm{D}$ relative to $6 \mathrm{~B}, \mathrm{C})$.

Among the picoplanktonic phytoplankton, the cyanobacteria (Synechococcus spp. and Prochlorococcusspp.) increased in abundance throughout the diversion by nearly an order of magnitude, andthen decreased rapidly to pre-diversion values within one week after the event (Fig. 6E). Picoplanktonic eukaryotic algae showed less consistent changes in abundances across the sampling stations during the diversion, but overall exhibited higher relative to abundances pre- and pre-diversion (Fig. 6F).

\subsubsection{Bacterial biomass, phytoplankton biomassand grazer response}

Bacteria exhibited a pattern of increasing cell abundances during the diversion, with a particularly large community response across all stationson September 25 (Fig.7A). Overall, bacterial abundances in surface waters during the diversion ranged from approximately 2 -fold to nearly an order of magnitude above pre-diversion values. The average abundanceof bacteria across the sampling stations pre-diversion was $7.96 \times 10^{5}$ bacteria $\mathrm{ml}^{-1}$. The overall average during the mid-diversion period (September 25) across

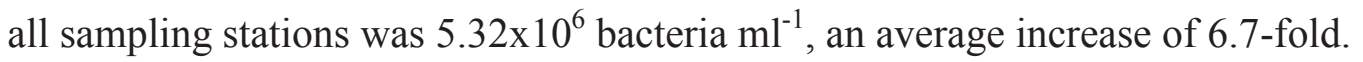
Bacterial abundances were highly variable across the geographic range of the study during the diversion, with values at some stations $>9 \times 10^{6}$ bacteria $\mathrm{ml}^{-1}$. Abundances at all stations decreased to approximately pre-diversion values (average $=9.47 \times 10^{5} \mathrm{ml}^{-1}$ withinone week after the diversion (Fig. 7A). 
A comparison of total bacterial biomass and phytoplankton biomass $\left(\mu \mathrm{g} \mathrm{C}^{-1}\right)$ revealed that these assemblages represented roughly comparable, although spatially and temporally variable,living biomassprior to and during the diversion (Fig. 7C,D). Phytoplankton biomass averaged $12.1 \pm 9.5$ and $43.9 \pm 43.0 \mu \mathrm{g} \mathrm{C}^{-1}$ prior to and during the diversion, while bacterialbiomass averaged 16.2 \pm 7.7 and $50.8 \pm 36.4 \mu \mathrm{g} \mathrm{Cl}^{-1}$ for these periods, respectively.

Microplanktonic consumers $>10 \mu \mathrm{m}$ (ciliates and heterotrophic dinoflagellates) also increased during the diversion event, although there was considerable variability among stations on each day(Fig. 7B). Abundances were consistently $<1 \mathrm{ml}^{-1}$ prior to the diversion, increased at several stations to $>10 \mathrm{ml}^{-1}$ during the diversion, and then decreased to values $<5 \mathrm{ml}^{-1}$ post-diversion.

\subsubsection{Contribution of phytoplankton, bacteria and ammonium to the nitrogen budget of plume-affected water}

A 3-way comparison of the nitrogen contained in the phytoplankton, bacteria, or present as ammonium in the plume-affected samples revealed a modest response of the phytoplankton, but a considerable response by the bacterial assemblage to effluent nitrogen (Fig. 8A). Samples collected during the pre-diversion period had minor contributions of phytoplankton-N $(\approx 6 \%)$ or bacterial-N $(\approx 12 \%)$ to total-N (shaded circles in Fig. 8A). Ammonium constituted $>80 \%$ of total-N in some of those samples, indicating either a recent contribution of ammonium from the $8 \mathrm{~km}$ pipe at that time (i.e., too recently for utilization by the biological community), or perhaps that phytoplankton and bacteriasimply constituted a minor component of nitrogen in the water column relative to the inorganic pool of nitrogen. Total-N averaged $2.17 \mu \mathrm{M}$ for the prediversion samples.Estimated averages for phytoplankton-N and bacterial-N for the prediversion samples were 0.14 and $0.27 \mu \mathrm{M}$ nitrogen, respectively (corresponding to $0.48 \mu \mathrm{g}$ chlorophyll $1^{-1}$ and $8.13 \times 10^{5}$ bacteria $\mathrm{ml}^{-1}$; see Methods and Materials).

Samples collected during and following the diversion had substantial contributions of bacterial-N to total-N. Bacterial-N averaged $42 \%$ of total-N for all samples during and after the diversion, while phytoplankton averaged 21\%(Fig. 8B). Several samples during 
and following the diversion in which ammonium concentrations were undetectable had high proportions of nitrogen present in the bacterial assemblage (60-90\%; Fig. 8A; samples falling on the right side of the triangle where ammonium $=0$ ). In contrast, phytoplankton- $\mathrm{N}$ was $\geq 40 \%$ of total- $\mathrm{N}$ in less than $9 \%$ of the samples, and constituted more than $60 \%$ of total-N in only one sample (note lack of symbols in the upper portion of Fig. 8 A).

\section{Discussion}

\subsection{Nutrients in released effluent, and stimulation of algal blooms}

Mounting evidence indicates that, globally, eutrophication as a result of human activities along coastal ecosystems plays a role in the frequency of algal blooms and HAB events, includingthe west coast of North America (Glibert et al., 2005; Anderson et al., 2008; Heisler et al., 2008; Kudela et al., 2008).A direct connection between effluent discharge in the Southern California Bight (SCB) and HABs, however, has been established only rarely.

Locally in the SCB, Reifel et al. (2013)investigated the response of the phytoplankton community to a discharge of secondarily-treated sewage by the Hyperion Treatment Plant (HTP; City of Los Angeles) into Santa Monica Bay during November, 2006, approximately $40 \mathrm{~km}$ north of the present study site. The discharge took place $1.6 \mathrm{~km}$ from shore at a depth of approximately $15 \mathrm{~m}$, and ammonium concentrations in the undiluted effluent were approximately $2 \mathrm{mM}$ (conditions similar to the present study). However, the HTP diversion took place foronly $\approx 2$ days, compared to the 3-week diversion by OCSD. Other differences from the present study includedmore restrictive hydrology in Santa Monica Bay leading to less initial dilution of the effluent plume, but also strong offshore winds(Santa Ana winds)that occurred throughout the period of the HTPdiversion and acted to drive the buoyant effluent plume directly offshore to the west of the north-south coastline.

The outcome of the HTP diversion differed from the present study.While the impact of the 2-day discharge was short-lived, the phytoplankton community mounted a 
considerable albeit spatially restricted response to the discharged nutrients. Chlorophyll concentrations $>100 \mu \mathrm{g} \mathrm{l}^{-1}$ were observed within one week of effluent releaseassociated with small patches of plume-affected surface water offshore from the discharge point. Dinoflagellates dominated the phytoplankton community in the study by Reifel et al. (2013), andseveral potentially-harmful species,Akashiwo sanguinea and Cochlodinium sp. (subsequently identified as C. fulvescens) (Howard et al., 2012), were important contributors in samples collected in the diluted plume.

The results obtained in the present study were remarkable in light of thechangesin the taxonomic composition andoverall strong response of phytoplankton standing stocks to the 2006HTP diversion. Chlorophyll concentrations observed in the discrete samplesobtained throughout this study ofthe OCSD diversion (pre-, during-, or postdiversion; Fig. 6A)were all1-2 orders of magnitude less than the highest values obtained by Reifel et al. (2013), and larger algae in the present study were dominated by diatoms rather than dinoflagellates (note different scales forY axes in Fig. 6B,C).

The potential for a strong response of the phytoplankton community to the release of OCSD effluent was demonstrated experimentally using incubations of natural plankton communities, supplemented with effluent diluted to $1: 10,1: 100$ or 1:1000 to mimic effluent released into the environment over a range of dilutions(Seubert et al., Submitted). The results of those experiments revealed a dramatic response of specific components of the phytoplankton community (especially diatoms) to diluted effluent during 7-day experiments. Total phytoplankton biomass estimated as chlorophyll $a$ in that studyincreased by two orders of magnitude $\left(>100 \mu \mathrm{g}^{-1}\right)$ by the end of the experiments when incubated with effluent diluted 1:10 or 1:100 at ambient light and temperature. The reason for the discrepancy between the outcomes of the incubation experiments and the response of the coastal community to effluent release is not clear, but may be related to differences between effluent employed in the incubation experiments and that released at the outfall (see Section 4.3).

Explanations for the large differences observed in the response of phytoplankton biomass between the HTP diversion and the field observations presented here are also difficult to define. The HTP diversion took place at a time when standing stocks of phytoplankton were somewhat elevated (1.1-9.8 $\mu \mathrm{g}$ chlorophyll $\left.\mathrm{l}^{-1}\right)$ relative to the pre- 
OSCD diversion values observed along the coast near Newport Beach (values $=0.20$ $1.02 \mu \mathrm{g}$ chlorophyll $\mathrm{I}^{-1}$ ), perhaps contributing to faster response of the community in during the HTP diversion in 2006. Some of the differencescanalso presumably be ascribedto the different hydrographies of the two locations. The OCSD $1.6 \mathrm{~km}$ outfallis positioned along an open, active coastline while the HTPoutfall is positioned at the closed end of a semi-enclosed body of water (Santa Monica Bay). Regardless of the explanation, the absence of a major (or minor) phytoplankton bloom during the OCSD diversion was unexpected and in striking contrast to the outcome of the much shorter HTP diversion.

\subsection{Anticipated nutrient loading and response of coastal watersfrom the OCSD effluent diversion}

Net alongshore transport of wateralong the San Pedro shelf is generally down-coast, with tidal modulation resulting in frequent short-term reversals of down-coastand up-coast transport of water, andepisodic atmospheric forcing events contributing a strong offshore component(Jones et al., 2002; Uchimaya et al., 2014). No major wind events occurred during the period of nearshore effluent discharge during Fall 2012, and the temperature structure of the water column did not indicate wind-induced upwelling events (Supplemental Fig. S2). Therefore, tidal modulation was a stronginfluence on water movement in the region during the OCSD diversion. Current predictions from theRegional Ocean Modeling System (ROMS)(Farrara et al., Submitted) and the results of drifter studies conducted during the diversion support this conclusion (2012 Orange County Sanitation District (OCSD) Outfall Diversion -Summary Report; available at http://www.sccoos.org/projects/2012-ocsd-outfall-repair-diversion/).

The relatively benign physical oceanographic conditions existing during the 2012 diversion indicated that water was not rapidly advected from the study area, and therefore should have resulted in patches of nutrient concentrations that were considerably increased relative to typical values in surface waters. Jones and Caron (2011) estimated the potential for the formation of patches of high-nutrient water based on inorganic nitrogen and phosphorus in the effluent, anticipated initial dilution of the effluentat the 
point of discharge (25:1 to $42: 1)$, and subsequent net water movement including tidal pulsing. Theyestimatedthat effluentreleasecould haveresulted in patches of water with total inorganic nitrogen concentrations $>40 \mu \mathrm{M}$, values that could support a phytoplankton bloomas great as the most intense phytoplankton blooms that have been observed in the SCB, based on remotely sensed chlorophyll fluorescence and extracted chlorophyll measured from discrete samplescollectly weekly during the past six years at piers in the region (http://www.sccoos.org/data/habs/)(Kim et al., 2009; Nezlin et al., 2012; Seubert et al., 2013). Concentrations of ammonium or total-N (ammonium-N + phytoplankton-N + bacterial-N) in some of the discrete samples collected during the cruises near the discharge site were consistent with expectations of high total-N in some samples (values $>20 \mu \mathrm{M}$, Fig. 4A).

\subsection{Phytoplankton response during the OCSD diversiondid not explain the fate of effluent nutrients}

Why, then, was a demonstrable phytoplankton bloom during or immediately following the OCSD diversion not observed in the present study? An obvious partial explanation would be that dilution of the effluent plume was more rapid than anticipated. Seubert et al. (Submitted) noted little detectable response of total phytoplankton biomass (i.e. extracted chlorophyll) by the addition of effluent diluted 1:1000, although dilutions of $1: 100$ or $1: 10$ resulted in substantial increases. Approximately $1 / 3$ of the total number of discrete samples from the ship surveys had total-N values $>2 \mu \mathrm{M}$, with some samples much higher (Fig. 4A). Converted to phytoplankton chlorophyll ( $\mathrm{C}: \mathrm{N}$ by atoms $=7$; $\mathrm{C}: \mathrm{Chl}=25)$, such values of total-Ncould have yielded extracted chlorophyll

concentrations of $\geq 7 \mu \mathrm{g} 1^{-1}$. Such values were not observed in this study (with the exception of one outlier; Fig. 6A).Moreover, the relatively low chlorophyll values measured in discrete samples during this study were consistent with observations obtained using in-situinstrumentation presented here (Figs. 2C, 3C), and from remote sensing and in-situ instrumentation presented in other papers of this special issue(Gierach et al., Submitted; Lucas and Kudela, Submitted).These findings make it unlikely that patches of high phytoplankton biomass were present but undetected during the study. 
Clearly, some mitigating factor(s) prevented growth of the phytoplankton in situ during the diversion. The highest ammonium values observed in the vicinity of the discharge may indicate that the release was very recent and there was insufficient time for the available nutrients to betaken up by the biological community. The phytoplankton assemblages in the experiments of Seubert et al.(Submitted)conducted using coastal water collected prior to the diversion experienced a 3-day lag in the growth of the phytoplankton community following effluent addition. The highest concentration of effluent resulted in a marked decrease in chlorophyll during the lag period (Seubert et al., Submitted).

Evidence presented by Kudela et al. (Submitted) implicated a direct, negative effect on phytoplankton photophysiology fromdisinfection byproducts contained in the effluent. These results are consistent with an initial lag in phytoplankton growthofthe coastal phytoplankton community observed in incubated water samples (Seubert et al., Submitted) but they do not necessarily explain why phytoplankton biomass did not increase at any time during the diversion or even weeks following effluent discharge.

A rapid increase in the grazer community could also mitigate rapid phytoplankton growth if grazing pressure increased concomitantly with phytoplankton growth. Increasesin grazer abundances occurred during the diversion (Fig. 7B)and it is conceivable that grazing activities played a role in deterring bloom formation. However, it seems unlikely that increased grazer activity can completely explain the lack of response of phytoplankton giventhe magnitude of growth-stimulating nutrients contained in the effluent.

\subsection{The role of bacteria in nutrient acquisition}

A unique finding of this study was the positive response of the bacteria to the OCSD diversion (Figs. 6E, 7A,C), and the inverse relationship (albeit weak) between bacterial-N and salinity (Fig. 5C). Abundances of bacteria increasedduring mid-diversion up to an order of magnitude greater than abundances prior to the diversionat some stations. These increases in bacterial carbon biomass were comparable to and on some dates exceeded the carbon biomass of the phytoplankton. Spatial heterogeneity of bacterial 
abundanceswas substantial over the entire study area, but the median abundance of bacteria on September 25 was particularly high $\left(>8 \times 10^{6}\right.$ bacteria $\left.\mathrm{ml}^{-1}\right)$.These high abundances are in accordance with the results of experiments with natural plankton assemblages incubated with1:10 or 1:100 diluted effluent(Seubert et al., Submitted). Bacteria in those experiments attained abundances $>10^{7} \mathrm{ml}^{-1}$. Such abundances are exceptionally high for natural coastal environments(Ducklow and Carlson, 1992), and their corresponding carbon and nutrient contents constituted an important componentof the living biomass and nutrient pools ofthe plankton community.

Bacteria have been shown to constitute a major fraction $(\approx 20-60 \%)$ of the total particulate organic matter in marine plankton communities, particularlyin oligotrophic ecosystems(Cho and Azam, 1990; Roman et al., 1995). Bacterial biomass values in coastal ecosystems with chlorophyll concentrations similar to those observed in the present study $\left(<5 \mu \mathrm{g}^{-1}\right)$ aretypically $1 / 2$ the phytoplanktonbiomass(Cho and Azam, 1990). Increases in bacterial abundances of 6.7-fold during the diversion resulted in this assemblage comprising a substantial amount of the living carbon biomass in the plankton (Fig. 7C). Moreover, bacteria are generally rich in nitrogen and phosphorus relative to eukaryotic plankton (Caron, 1994; Fukuda et al., 1998). Some C:N values observed for the particulate material in the plankton during the OCSD diversion were quite low $(<3)$ (McLaughlin et al., Submitted).Such values are consistent with the dominance of bacterial nitrogen in the water during the diversion (Fig. 8) because bacteria are the only microbial assemblage with such low C:N values (Goldman et al., 1987).

The high bacterial abundances observed during the diversion reflectedsubstantial net growth of the bacterial community. Increases in bacterial abundances during the diversion cannot be explained by thecontribution of bacterial cells present inthe effluent. Initial abundances of bacteria in the experiments of Seubert et al.(Submitted) subjected to 1:10 and 1:100 dilutions of effluent were not higher thanbacterial abundancesin the natural community. Therefore, only net population growth of the natural assemblage of bacteria could explain their increases during the diversion.

Increases in bacterial abundances in the water imply that considerable bacterial substrate was available for bacterial growth during the diversion. The source(s) supporting that growth in the present study is not clear. Labile organic material may have 
been released as a consequence of the effects of disinfection byproducts on the phytoplankton assemblage (Kudela et al., Submitted).Effluent also contains particulate and dissolved organic carbon that may be important sources of allochthonous substrates for bacterial growth, as evidenced by measureable rates of residual biological oxygen demand (BOD) in the OCSD effluent. Although uncharacterized in the present study, Lyon and Sutula (2011) reported BODs that averaged $45.5 \mathrm{mg} \mathrm{l}^{-1}$ in effluent from 2005 to 2009 , indicating that organic compounds in effluent may have constituted a source of bacterial substrate in the receiving coastal waters. Finally, high rates of nitrificationin the proximity of the $8 \mathrm{~km}$ OCSD outfall(McLaughlin et al., Submitted) may have contributed to increases in bacterial growth and standing stocks in water affected by effluent.

The specific source(s) of bacterial substrate remains enigmatic, but the development of high abundances of bacteria in this coastal ecosystemduring the diversionresulted in bacterial biomass constitutinga considerableproportion of the living carbon and nutrients during the diversion (Figs. 7C, 8). We speculate that this situation may characterize a generalized response of the human-natural coupling of effluent nutrients (and attendant particulate and dissolved organic matter) into the pelagic food web of coastal southern California in the vicinity of POTWs.Additionally, this scenarioimpliesthat minute bacterivorous protists and phages must play pivotal ecological roles by consuming or lysing bacteria and cyanobacteria, remineralizing major nutrients contained in their biomass and thereby making those nutrients available to phytoplankton(Caron, 1994; Strom, 2000; Sherr and Sherr, 2002). Increased abundances of bacteria may also stimulate shifts in the phytoplankton community towards greater contributions by phagotrophic (mixotrophic) algae to total algal biomass because some of those species are capable of meeting major nutrient requirements via the ingestion and digestion of bacterial prey(Stoecker, 1998; Mitra and Flynn, 2010; Sanders, 2011). The timing of nutrient release mediated by these sources of bacterial mortality, relative to advection and dilution of the effluent, is fundamental in determining the impact of nutrients contained in effluent on the development of algal blooms.

\section{Conclusion}


The Orange County Sanitation District effluent diversion during 2012 along the San Pedro shelf in the Southern California Bight resulted in increasesin phytoplankton biomass (i.e. chlorophyll concentrations) that generally remained well below historical values of minor blooms in this shallow coastal ecosystem. Changes in phytoplankton community composition were observed during the diversion, but increases in major taxonomic groups were temporally offset. Bacterial biomass increased substantially through mid-diversion, and constituted a sizeable fraction of the total nitrogen in the planktonic community from mid- through post-diversion. We speculate that the ability of the bacterial assemblage to capture much of the available nitrogen in the ecosystem may have beenenabled by a deleterious effect of disinfection byproductson phytoplanktonphotophysiology, and increased availability of labile organic substrates for bacterial growthin the discharged effluent. Immobilization of macronutrientsin the bacterial biomass may havedelayed the utilization of nutrientsreleased in the effluent by the phytoplankton assemblage until dilution and advection reduced the impact of the effluent on the planktonic community in the region. These findings implicate an important role for the microbial loop component of the pelagic food web during these events.

\section{Acknowledgments}

We are grateful to the captains and crews of the M/V Nerissa and R/V Yellowfin for assistance with the shipboard work. Funding for this study was provided by National Oceanic and Atmospheric Administration grants NA11NOS4780052 and subaward NA08OAR4320894 (DC) and NA11NOS4780030 (RMK and MDH), the National Science Foundation through RAPID award OCE1251573 (RMK and AJL), the Southern California Coastal Water Research Project Authority,and as in-kind support from the Orange County Sanitation District for access to research vessels and field sampling equipment. This is NOAA ECOHAB Publication Number 818.

\section{References}


Anderson, D.M., Glibert, P.M., Burkholder, J.M., 2002. Harmful algal blooms and eutrophication: nutrient sources, composition, and consequences. Estuaries 25,704726.

Anderson, D.M., Burkholder, J.M., Cochlan, W.P., Glibert, P.M., Gobler, C.J., Heil, C.A., Kudela, R.M., Parsons, M.L., Rensel, J.E.J., Townsend, D.W., Trainer, V.L., Vargo, G.A., 2008. Harmful algal blooms and eutrophication: examining linkages from selected coastal regions of the United States. Harmful Algae 8,39-53.

Buitenhuis, E.T., Li, W.K.W., Lomas, M.W., Karl, D.M., Landry, M.R., Jacquet, S., 2012. Bacterial biomass distribution in the global ocean. Earth Systems Science Data Discussions 5,301-315.

Capone, D.G., Hutchins, D.A., 2013. Microbial biogeochemistry of coastal upwelling regimes in a changing ocean. Nature Geosci. 6,711-717.

Caron, D.A., 1994. Inorganic nutrients, bacteria and the microbial loop. Microb. Ecol. 28,295-298.

Caron, D.A., Garneau, M.-v., Seubert, E., Howard, M.D.A., Darjany, L., Schnetzer, A., Cetinic, I., Filteau, G., Lauri, P., Jones, B., Trussell, S., 2010. Harmful algae and their potential impacts on desalination operations off southern California. Water Res. $44,385-416$.

Carr, M.-E., 2001. Estimation of potential productivity in Eastern Boundary Currents using remote sensing. Deep-Sea Res. II 49,59-80.

Chavez, F.P., Messié, M., 2009. A comparison of Eastern Boundary Upwelling Ecosystems. Prog. Oceanogr. 83,80-96.

Checkley, D.M., Barth, J.A., 2009. Patterns and processes in the California Current System. Prog. Oceanogr. 83,49-64.

Cho, B.C., Azam, F., 1990. Biogeochemical significance of bacterial biomass in the ocean's euphotic zone. Mar. Ecol. Prog. Ser. 63,253-259.

Collos, Y., Harrison, P.J., 2014. Acclimation and toxicity of high ammonium concentrations to unicellular algae. Mar. Poll. Bull. 80,8-23.

Cullen, J.J., Eppley, R.W., 1981. Chlorophyll maximum layers of the Southern California Bight and possible mechanisms of their formation and maintenance. Oceanologica Acta 4,23-32. 
del Giorgio, P.A., Bird, D.F., Prairie, Y.T., Planas, D., 1996. Flow cytometric determination of bacterial abundance in lake plankton with the green nucleic acid stain SYTO 13. Appl. Environ. Microbiol. 41,783-789.

Dortch, Q., 1990. The interaction between ammonium and nitrate uptake in phytoplankton. Mar. Ecol. Prog. Ser. 61,183-201.

Dortch, Q., Conway, H.L., 1984. Interactions between nitrate and ammonium uptake: variation with growth rate, nitrogen source and species. Mar. Biol. 79,151-164.

Ducklow, H.W., Carlson, C.A., 1992. Oceanic bacterial production. Adv. Microb. Ecol. 12,113-181.

Dugdale, R., Wilkerson, F., Hogue, V., Marchi, A., 2007. The role of ammonium and nitrate in spring bloom development in San Francisco Bay. Estuar. Coast. Shelf Sci. $73,17-29$.

Farrara, J.D., Chao, Y., Zhang, H., Howard, M.D.A., Jones, B., Robertson, G., Rogowski, P., Seegers, B., Teel, E., Submitted. Oceanographic conditions during the OCSD diversion experiment as revealed by observations and model simulations. Estuar. Coast. Shelf Sci.

Fukuda, R., Ogawa, H., Nagata, T., Koike, I., 1998. Direct determination of carbon and nitrogen contents of natural bacterial assemblages in marine environments. Appl. Environ. Microbiol. 64,3352-3358.

Garneau, M.-E., Schnetzer, A., Countway, P.D., Jones, A.C., Seubert, E.L., Caron, D.A., 2011. Examination of the seasonal dynamics of the toxic dinoflagellate Alexandrium catenella at Redondo Beach, California, by quantitative PCR. Appl. Environ. Microbiol. 77,7669-7680.

Gierach, M.M., Holt, B., Trinh, R., Pan, B., Rains, C., Submitted. Satellite detection of wastewater diversion plumes in southern California. Estuar. Coast. Shelf Sci.

Glibert, P.M., Seitzinger, S., Heil, C.A., Burkholder, J.M., Parrow, M.W., Codispoti, L.A., Kelly, V., 2005. The role of eutrophication in the global proliferation of harmful algal blooms. Oceanography 18,198-209.

Goldman, J.C., Caron, D.A., Dennett, M.R., 1987. Regulation of gross growth efficiency and ammonium regeneration in bacteria by substrate $\mathrm{C}: \mathrm{N}$ ratio. Limnol. Oceanogr. $32,1239-1252$. 
Greenfield, D., Marin, R., Doucette, G., Mikulski, C., Jones, K., Jensen, S., Roman, B., Alvarado, N., JFeldman, J., Scholin, C., 2008. Field applications of the secondgeneration Environmental Sample Processor (ESP) for remote detection of harmful algae: 2006-2007. Limnol. Oceanogr. Methods 6,667-679.

Gregorio, D.E., Pieper, R.E., 2000. Investigations of red tides along the southern California coast. Bull. So. Cal. Acad. Sci. 99,147-160.

Heisler, J., Glibert, P.M., Burkholder, J.M., Anderson, D.M., Cochlan, W., Dennison, W.C., Dortch, Q., Gobler, C.J., Heil, C.A., Humphries, E., Lewitus, A.J., Magnien, R., Marshall, H.G., Sellner, K., Stockwell, D.A., Stoecker, D.K., Suddleson, M., 2008. Eutrophication and harmful algal blooms: a scientific consensus. Harmful Algae 8,3-13.

Hickey, B.M., 1992. Circulation over the Santa Monica - San Pedro basin and shelf. Prog. Oceanogr. 30,37-115.

Holmes, R.W., Williams, P.M., Eppley, R.W., 1967. Red water in La Jolla Bay, 19641966. Limnol. Oceanogr. 12,503-512.

Howard, M.D.A., Kudela, R.M., McLaughlin, K.A., Submitted. New insights into impacts of anthropogenic nutrients on urban ecosystem processes on the Southern California coastal shelf: Introduction and synthesis. Estuar. Coast. Shelf Sci.

Howard, M.D.A., Jones, A.C., Schnetzer, A., Countway, P.D., Tomas, C.R., Kudela, R.M., Hayashi, K., Chia, P., Caron, D.A., 2012. Quantitative real-time PCR for Cochlodinium fulvescens (Dinophyceae), a potentially harmful dinoflagellate from California coastal waters. J. Phycol. 48,384-393.

Howard, M.D.A., Sutula, M., Caron, D.A., Chao, Y., Farrara, J.D., Frenzel, H., Jones, B., Robertson, G., McLaughlin, K., Sengupta, A., 2014. Anthropogenic nutrient sources rival natural sources on small scales in the coastal waters of the Southern California Bight. Limnol. Oceanogr. 59,285-297.

IGODS (2012) IGODS (Interactive Graphical Ocean Database System) Version 3 Beta 4.44. Ocean Software and Environmental Consulting. Jessup, D.A., Miller, M.A., Ryan, J.P., Nevins, H.M., Kerkering, H.A., Mekebri, A., Crane, D.B., Johnson, T.A., Kudela, R.M., 2009. Mass Stranding of Marine Birds Caused by a Surfactant-Producing Red Tide. PLoS One 4,e4550. 
Jones, B.H., Caron, D.A. (2011) Anticipated biological response to extended discharge from a nearshore, shallow outfall. Fountain Valley, CA, Orange County Sanitation District.

Jones, B.H., Noble, M.A., Dickey, T.D., 2002. Hydrographic and particle distributions over the Palos Verdes Continental Shelf: spatial, seasonal and daily variability. Cont. Shelf Res. 22,945-965.

Kim, D.Y., Countway, P.D., Jones, A.C., Schnetzer, A., Yamashita, W., Tung, C., Caron, D.A., 2013. Monthly to interannual variability of microbial eukaryote assemblages at four depths in the eastern North Pacific. ISME J.

Kim, H.-J., Miller, A.J., McGowan, J., Carter, M.L., 2009. Coastal phytoplankton blooms in the Southern California Bight. Prog. Oceanogr. 82,137-147.

Kudela, R.M., Cochlan, W.P., 2000a. Nitrogen and carbon uptake kinetics and the influence of irradiance for a red tide bloom off southern California. Aq. Microb. Ecol. 21,31-47.

Kudela, R.M., Cochlan, W.P., 2000b. The kinetics of nitrogen and carbon uptake and the influence of irradiance for a natural population of Lingulodinium polyedrum (Pyrrophyta) off southern California. Aq. Microb. Ecol. 21,31-47.

Kudela, R.M., Lane, J.Q., Cochlan, W.P., 2008. The potential role of anthropogenically derived nitrogen in the growth of harmful algae in California, USA. Harmful Algae 8,103-110.

Kudela, R.M., Lucas, A.J., Negrey, K.H., Howard, M.D.A., McLaughlin, K., Submitted. Death from below: Investigation of inhibitory factors in bloom development during a wastewater effluent diversion. Estuar. Coast. Mar. Sci.

Lewitus, A.J., Horner, R.A., Caron, D.A., Garcia-Mendoza, E., Hickey, B.M., Hunter, M., Huppert, D.D., Kelly, D., Kudela, R.M., Langlois, G.W., Largier, J.L., Lessard, E.J., RaLonde, R., Rensell, J.E., Strutton, P.G., Trainer, V.L., Tweddle, J.F., 2012. Harmful algal blooms in the North American west coast region: history, trends, causes, and impacts. Harmful Algae 19,133-159.

Litchman, E., Klausmeier, C.A., Miller, J.R., Schofield, O.M., Falkowski, P.G., 2006. Multi-nutrient, multi-group model of present and future oceanic phytoplankton communities. Biogeosci. Disc. 3,607-663. 
Lucas, A.J., Kudela, R.M., Submitted. The fine-scale vertical variability of a wastewater discharge plume in stratifed waters. Estuar. Coast. Shelf Sci.

Lyon, G.S., Sutula, M.A. (2011) Effluent discharges to the Southern California Bight from large municipal wastewater treatment facilities from 2005 to 2009. Southern California Coastal Water Research Project Annual Report. Costa Mesa, Southern California Coastal Water Research Project.

Lyon, G.S., Petschauer, D., Stein, E.D. (2006) Effluent discharges to the Southern California Bight from large municipal wastewater treatment facilities in 2003 and 2004. Southern California Coatal Water Research Project Annual Report. Costa Mesa, Southern California Coastal Water Research Project.

McLaughlin, K., Howard, M.D.A., Beck, C.D.A., Kudela, R.M., Nezlin, N., Robertson, G., Submitted. Rapid nitrification of anthropogenic nitrogen from wastewater discharge into the coastal ocean, Southern California, USA. Estuar. Coast. Mar. Sci.

Mitra, A., Flynn, K.J., 2010. Modelling mixotrophy in harmful algal blooms: More or less the sum of the parts? J. Mar. Systems 83,158-169.

Nezlin, N.P., Sutula, M.A., Stumpf, R.P., Sengupta, A., 2012. Phytoplankton blooms detected by SeaWiFS along the central and southern California coast. J. Geophys. Res. (Oceans) 117.

Parsons, T.R., Maita, Y., Lalli, C.M. 1984. A manual of chemical and biological methods for seawater analysis. Pergamon Press, Oxford. p. 173.

Reifel, K.M., Corcoran, A.A., Cash, C., Shipe, R., Jones, B.H., 2013. Effects of a surfacing effluent plume on a coastal phytoplankton community. Cont. Shelf Res. 60,38-50.

Riemann, B., Simonsen, P., Stensgaard, L., 1989. The carbon and chlorophyll content of phytoplankton from various nutrient regimes. J. Plankton Res. 11,1037-1045.

Roman, M.R., Caron, D.A., Kremer, P., Lessard, E.J., Madin, L.P., Malone, T.C., Napp, J.M., Peele, E.R., Youngbluth, M.J., 1995. Spatial and temporal changes in the partitioning of organic carbon in the plankton community of the Sargasso Sea off Bermuda. Deep-Sea Res. I 42,973-992.

Ryan, J., Greenfield, D., Marin, R., Preston, C., Roman, B., Jensen, S., Pargett, D., Birch, J., Mikulski, C., Doucette, G., Scholin, C., 2011. Harmful phytoplankton ecology 
studies using an autonomous molecular analytical and ocean observing network. Limnol. Oceanogr. 56,1255-1272.

Ryan, J.P., McManus, M.A., Kudela, R.M., Lara Artigas, M., Bellingham, J.G., Chavez, F.P., Doucette, G., Foley, D., Godin, M., Harvey, J.B.J., Marin III, R., Messié, M., Mikulski, C., Pennington, T., Py, F., Rajan, K., Shulman, I., Wang, Z., Zhang, Y., 2014. Boundary influences on HAB phytoplankton ecology in a stratificationenhanced upwelling shadow. Deep-Sea Res. II 101,63-79.

Sanders, R.W., 2011. Alternative nutritional strategies in protists: symposium introduction and a review of freshwater protists that combine photosynthesis and heterotrophy1. J. Euk. Microbiol. 58,181-184.

Schnetzer, A., Jones, B.H., Schaffner, R.A., Cetinic, I., Fitzpatrick, E., Miller, P.E., Seubert, E.L., Caron, D.A., 2013. Coastal upwelling linked to toxic Pseudo-nitzschia australis blooms in Los Angeles coastal waters, 2005-2007. J. Plankton Res.

Schnetzer, A., Miller, P.E., Schnaffner, R.A., Stauffer, B.A., Jones, B.H., Weisberg, S.B., DiGiacomo, P.M., Berelson, W.M., Caron, D.A., 2007. Blooms of Pseudo-nitzschia and domoic acid in the San Pedro Channel and Los Angeles harbor areas of the Southern California Bight, 2003-2004. Harmful Algae 6,372-387.

Scholin, C.A. 2013. Ecogenomic Sensors. In: Levin, S.A. (ed.) Encyclopedia of Biodiversity. 2nd ed. Academic Press, Waltham, MA. 2, 690-700.

Sengupta, A., Sutula, M.A., McLaughlin, K., Howard, M., Tiefenthaler, L., Von Bitner, T. (2013) Terrestrial nutrient loads and fluxes to the Southern California Bight, USA. Southern California Coastal Water Research Project Annual Report. Costa Mesa.

Seubert, E.L., Gellene, A.G., Campbell, V., Smith, J., Robertson, G., D.A., C., Submitted. Response of a natural planktonic community to treated sewage effluent. Estuar. Coast. Mar. Sci.

Seubert, E.L., Howard, M.D.A., Kudela, R.M., Stewart, T.N., Litaker, R.W., Evans, R., Caron, D.A., 2014. Development, comparison and validation using ELISAs for the analysis of domoic acid in California sea lion body fluids. J. AOAC Inter. 97,345355.

Seubert, E.L., Gellene, A.G., Howard, M.D.A., Connell, P., Ragan, M., Jones, B.H., Runyan, J., Caron, D.A., 2013. Seasonal and annual dynamics of harmful algae and 
algal toxins revealed through weekly monitoring at two coastal ocean sites off southern California, USA. Environ. Sci. Pollution Res. 20,6878-6895.

Sherr, E.B., Sherr, B.F., 2002. Significance of predation by protists in aquatic microbial food webs. Antonie van Leeuwenhoek 81,293-308.

Stauffer, B.A., Gellene, A., Schnetzer, A., Seubert, E.L., Oberg, C., Sukhatme, G.S., Caron, D.A., 2012. An oceanographic, meterological and biological 'perfect storm' yields a massive fish kill. Mar. Ecol. Prog. Ser. 468,231-243.

Stein, E.D., Cadien, D.B., 2009. Ecosystem response to regulatory and management actions: The southern California experience in long-term monitoring. Mar. Poll. Bull. 59,91-100.

Stoecker, D.K., 1998. Conceptual models of mixotrophy in planktonic protists and some ecological and evolutionary implications. Europ. J. Protistol. 34,281-290.

Strom, S.L. 2000. Bacterivory: Interactions between bacteria and their grazers. In: Kirchman, D.L. (ed.) Microbial Ecology of the Oceans. Wiley-Liss, Inc., New York. 351-386.

Uchimaya, Y., Idica, E.Y., McWilliams, J.C., Stolzenbach, K.D., 2014. Wastewater effluent dispersal in southern California bays. Cont. Shelf Res. 76,36-52. 
Table 1.Average concentrations of extracted chlorophyll ain plume-affected, discrete samples obtained from ship surveys, summarized relative to timing of the effluent diversion (pre-diversion, 6-10 September 2012; during diversion, 11 September-2 October 2012; post-diversion, 3-17 October 2012). Samples were collected near the Surface (0-2 m) and the depth of the Subsurface Chlorophyll Maximum (SCM). 'Average' is the average for all samples obtained during a particular period (prediversion, during diversion,post-diversion). 'Range' is the range of chlorophyll values observed during that period. All units are $\mu \mathrm{g}$ chlorophyll $1^{-1}$. ' $*$ ' indicates a single sample.

\begin{tabular}{|l|c|c|c|c|c|c|}
\hline Depth & \multicolumn{2}{|c|}{ Pre-diversion } & \multicolumn{2}{c|}{ During Diversion } & \multicolumn{2}{c|}{ Post-diversion } \\
\hline & Average & Range & Average & Range & Average & Range \\
\hline Surface & 0.38 & $0.20-1.02$ & 1.82 & $0.04-9.85$ & 0.35 & $0.17-0.55$ \\
\hline SCM & 1.02 & $*$ & 1.69 & $0.26-5.12$ & 0.82 & $0.38-1.58$ \\
\hline Overall & 0.48 & $0.20-1.02$ & 1.75 & $0.04-9.85$ & 0.56 & $0.17-1.58$ \\
\hline
\end{tabular}




\section{Figure legends}

Figure 1. Map of the study area, and overview of cruise tracks and station locations along the San Pedro shelf in the Southern California Bight, eastern North Pacific. Stations sampled during the'plume-tracking' cruises (circles), the 'event' cruises (black triangles) and 'regional' cruise (shaded triangles in figure inset) are shown, as are the locations of the instrumented buoys (shaded squares) and Environmental Sample Processor (black square).See Supplemental Fig. S1 for the specific subset of stationsoccupied during each plume-tracking cruise. The specific stations occupied varied according to prevailing currents for each cruise day (red or yellow circles), but always included stations in the proximity of the outfall (orange circles). Station locations for the three plume-tracking cruises covering a larger geographical area are shown as blue circles. The Orange County Sanitation District $8 \mathrm{~km}$ effluent pipe and $1.6 \mathrm{~km}$ pipe, used during the 2012 diversion, are indicated on the map as black lines.

Figure 2. Water quality measurements and chlorophyll fluorescence observed on the instrumented buoys moored just north and south of the location of the OCSD outfall pipe $1.6 \mathrm{~km}$ from shore(see Fig. 1 for location relative to the $1.6 \mathrm{~km}$ outfall pipe).

(A)temperature, (B) salinity (Practical Salinity Scale), (C) chlorophyllfluorescence, (D) phosphate, (E) dissolved oxygen and (F) turbidity. Both sets of data are presented on each panel, the southern buoy did not carry a phosphate sensor. The black horizontal line shows the period of time when the effluent was diverted to the shallow outfall pipe.

Figure 3. Temperature (A), salinity (B), chlorophyll fluorescence (C) and the results of harmful algae hybridization assays (D) conducted aboard the Environmental Sample Processor (see Fig. 1 for location relative to the OCSD $1.6 \mathrm{~km}$ outfallpipe). Dates between the dotted vertical lines indicate the time when the effluent was diverted to the shallow outfall pipe. Blank areas in A,B,C indicate failure of a sensor.

Figure 4. Temperature-salinity diagrams with measured (ammonium) or calculated (phytoplankton, bacteria) nitrogen constituents plotted from 175 discrete samples from 
the plume-tracking, event and regional cruises. Total nitrogen $(\mathrm{A}$; ammonium + bacterial nitrogen + phytoplankton nitrogen), ammonium (B), bacterial nitrogen (C) and phytoplankton nitrogen (D) were determined as described in the text. The size of each dot is proportional to the concentration. All values in $\mu \mathrm{M}$.

Figure 5. Scatter plots of nitrogen constituents versus salinity in 108 plume-affected samples from the plume-tracking, event and regional cruise sample sets. Total nitrogen $(\mathrm{A}$; ammonium + bacterial nitrogen + phytoplankton nitrogen $)$, ammonium $(\mathrm{B})$, bacterial nitrogen (C) and phytoplankton nitrogen (D) were determined as described in the text. The 108 samples were obtained after culling based on temperature, depth and salinity as described in the text (equations and correlation coefficients $(\mathrm{R})$ for the regressions for A$\mathrm{D}$, respectively, were $\mathrm{Y}=-19.97 \mathrm{X}+669, \mathrm{R}=0.51 ; \mathrm{Y}=-9.02 \mathrm{X}+302, \mathrm{R}=0.26 ; \mathrm{Y}=$ $5.56 \mathrm{X}+186, \mathrm{R}=0.47 ; \mathrm{Y}=-5.39 \mathrm{X}+180, \mathrm{R}=0.58)$. One outlier was omitted from each plot (values off scale).

Figure 6. Box-and-whisker plots for extracted chlorophyllconcentrations $\left(\mu \mathrm{g}^{-1}: \mathrm{A}\right)$ and abundances of phytoplankton in 108 plume-affected samples from the plumetracking, event and regional cruise sample sets, organized by date of cruise. Phytoplankton taxa were grouped according to diatoms (B), dinoflagellates (C), 'other' microplanktonic phytoplankton species (D), cyanobacteria (Synechococcus + Prochlorococcus; E) and phototrophic picoeukaryotic algae (F). The darkly shaded area shows the period of time when the effluent was diverted to the shallow outfall pipe. Outliers are shown as black dots.Box plots made in R (http://www.R-project.org), using the ggplot2 package (http://ggplot2.org/). A coefficient of 3 was used as a multiple of the interquartile range (IQR) to determine the length of the whiskers.

Figure 7. Box-and-whisker plotsof abundances of bacteria (bacteria+archaea; A) and micrograzer $>10 \mu \mathrm{m}(\mathrm{B})$, and calculated values of carbon in the bacterial assemblage (C) and the phytoplankton assemblage (D)in 108 plume-affected samples from the plumetracking, event and regional cruise sample sets, organized by date of cruise. The darkly shaded area shows the period of time when the effluent was diverted to the shallow 
outfall pipe. Outliers are shown as black dots.Box plots made in R (http://www.Rproject.org), using the ggplot2 package (http://ggplot2.org/). A coefficient of 3 was used as a multiple of the interquartile range (IQR) to determine the length of the whiskers.

Figure 8. Triangular plot of the percent contribution of ammonium, bacterial nitrogen and phytoplankton nitrogen in 108 plume-affected samples from the plume-tracking, event and regional cruise sample sets,collected prior to, during and following the diversion. 


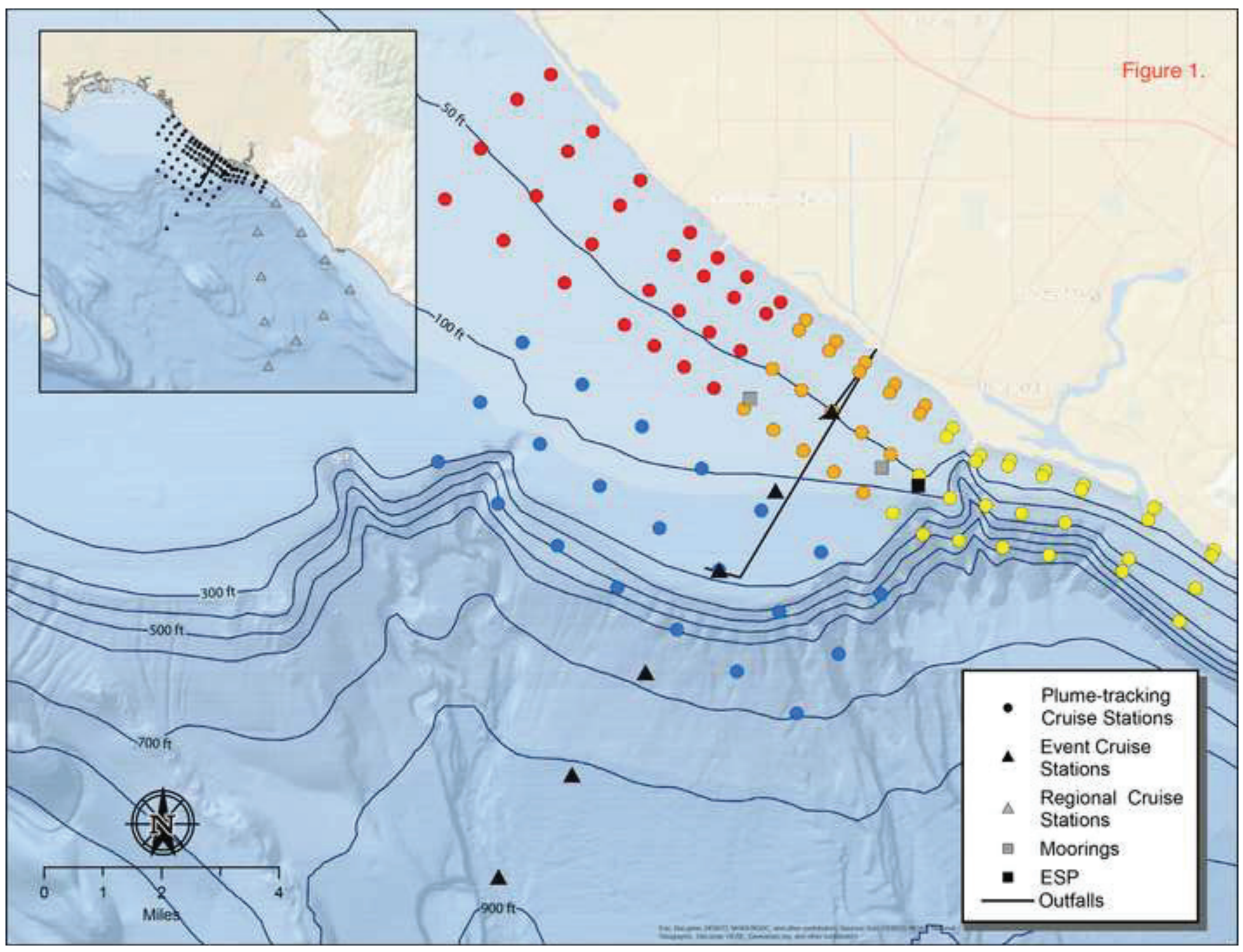



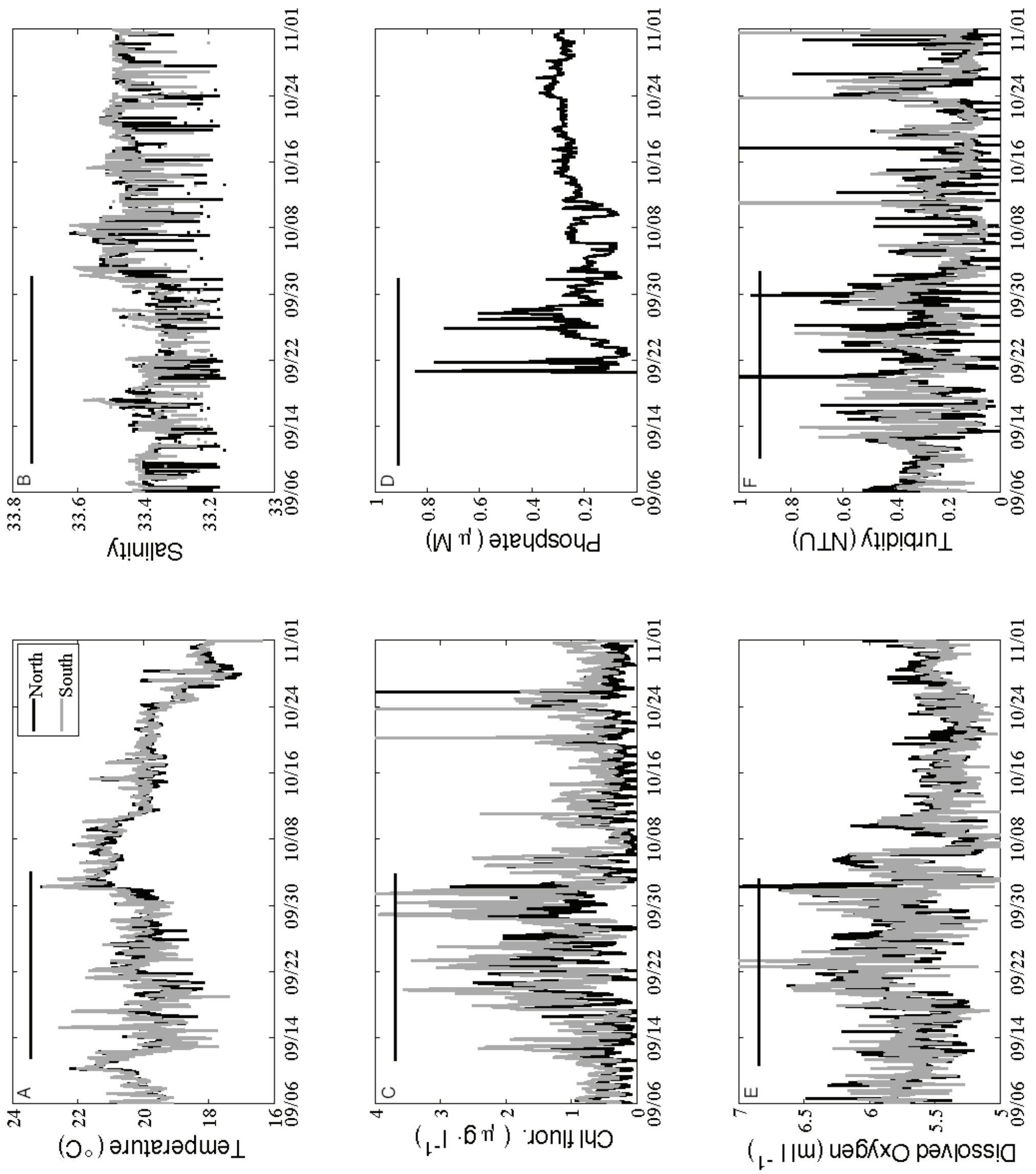


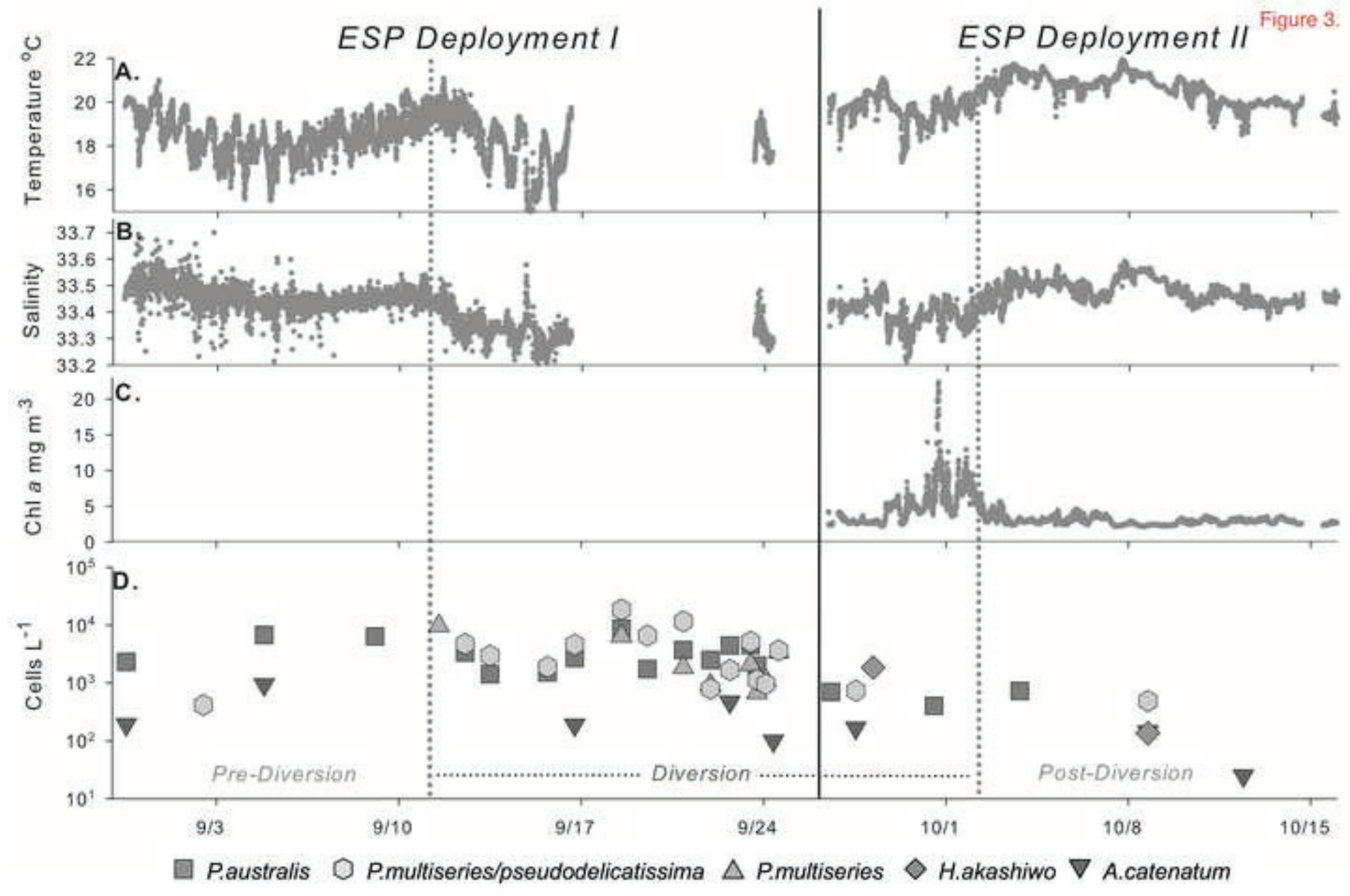



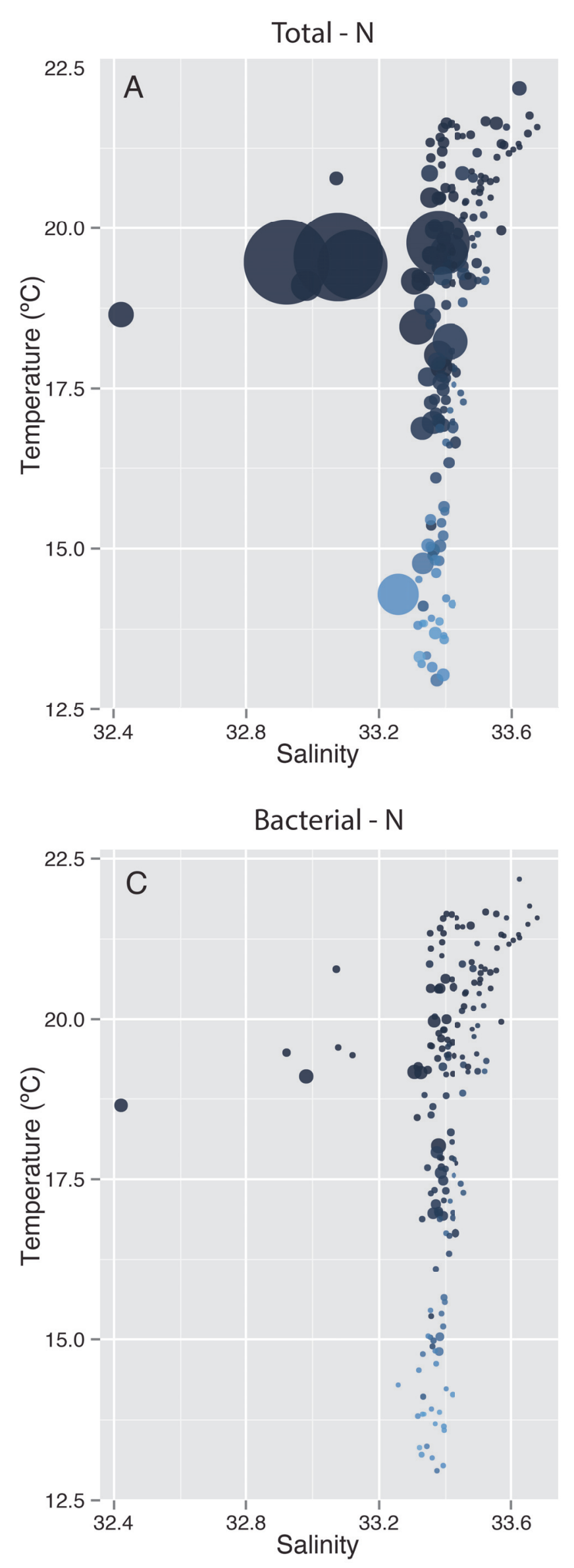

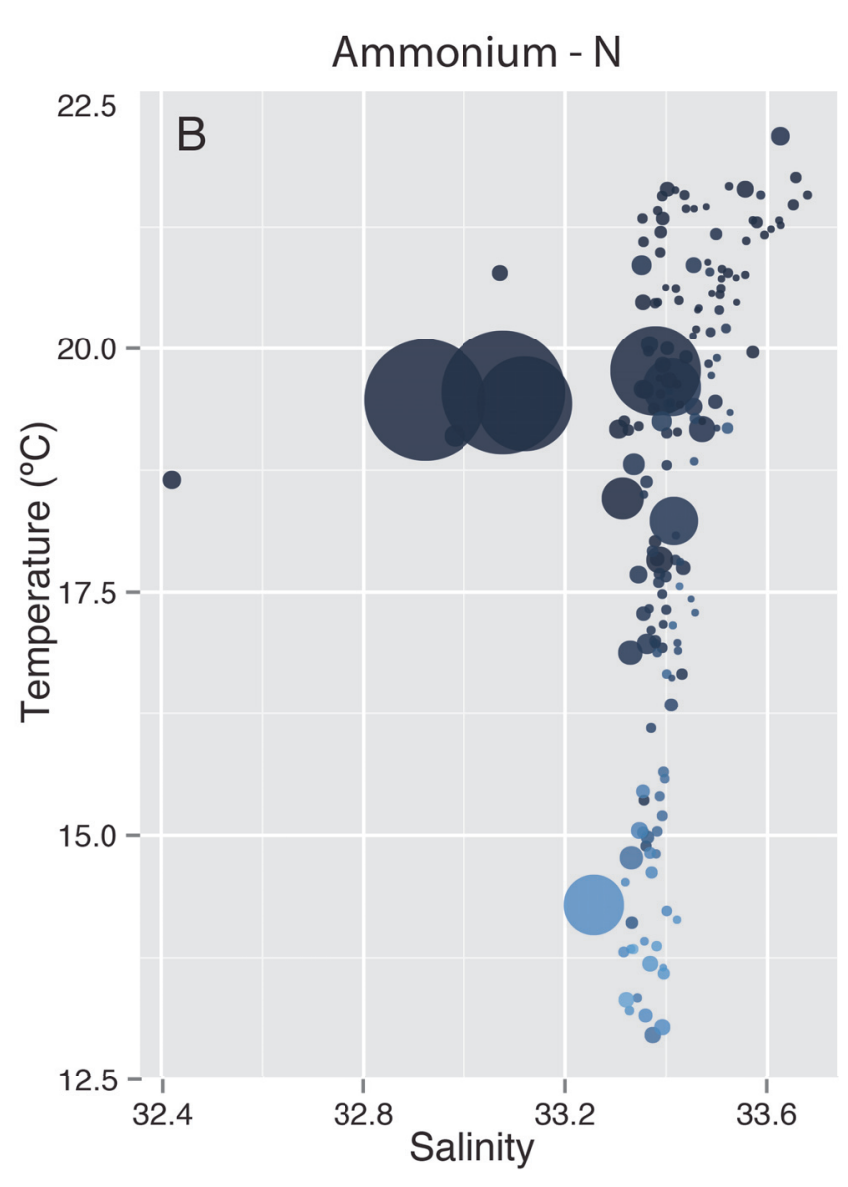

Figure 4.

Nitrogen $(\mu \mathrm{M})$

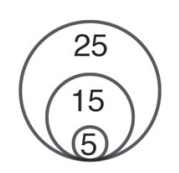

Depth (m)

10
20
30
40
-50

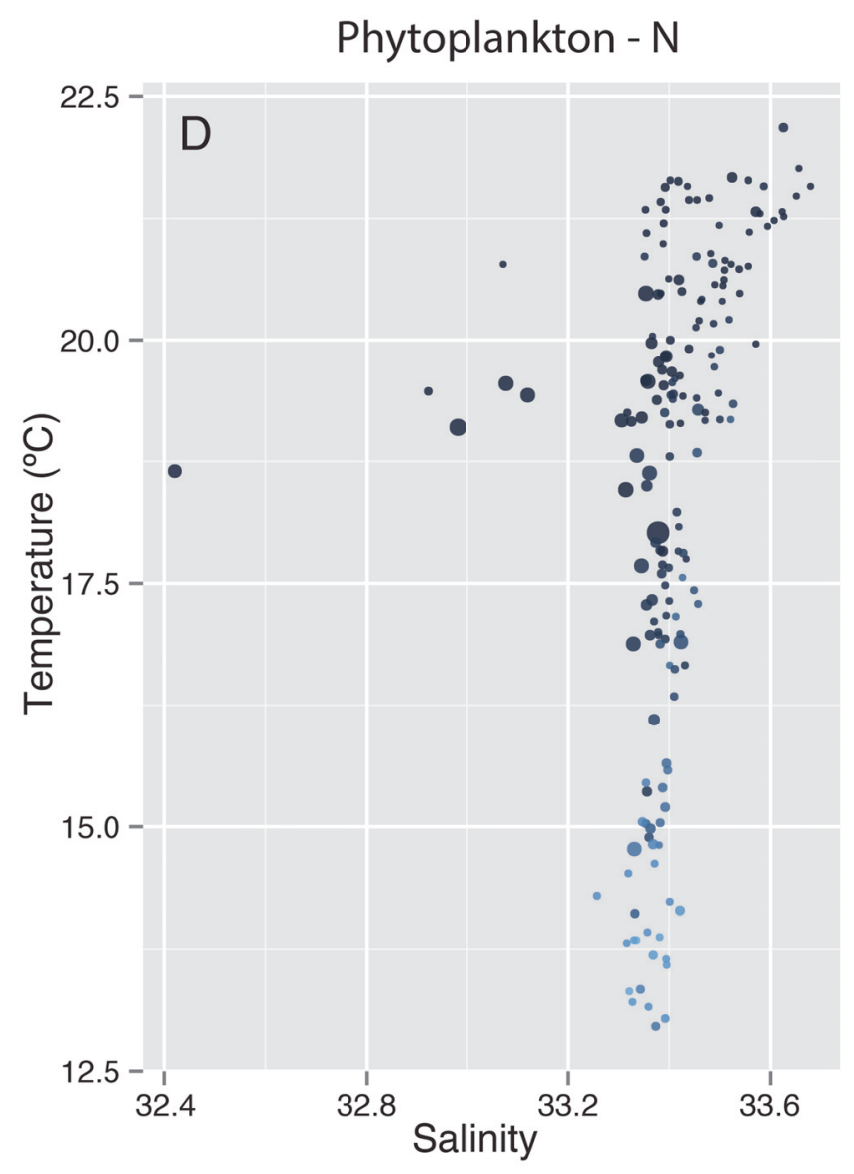



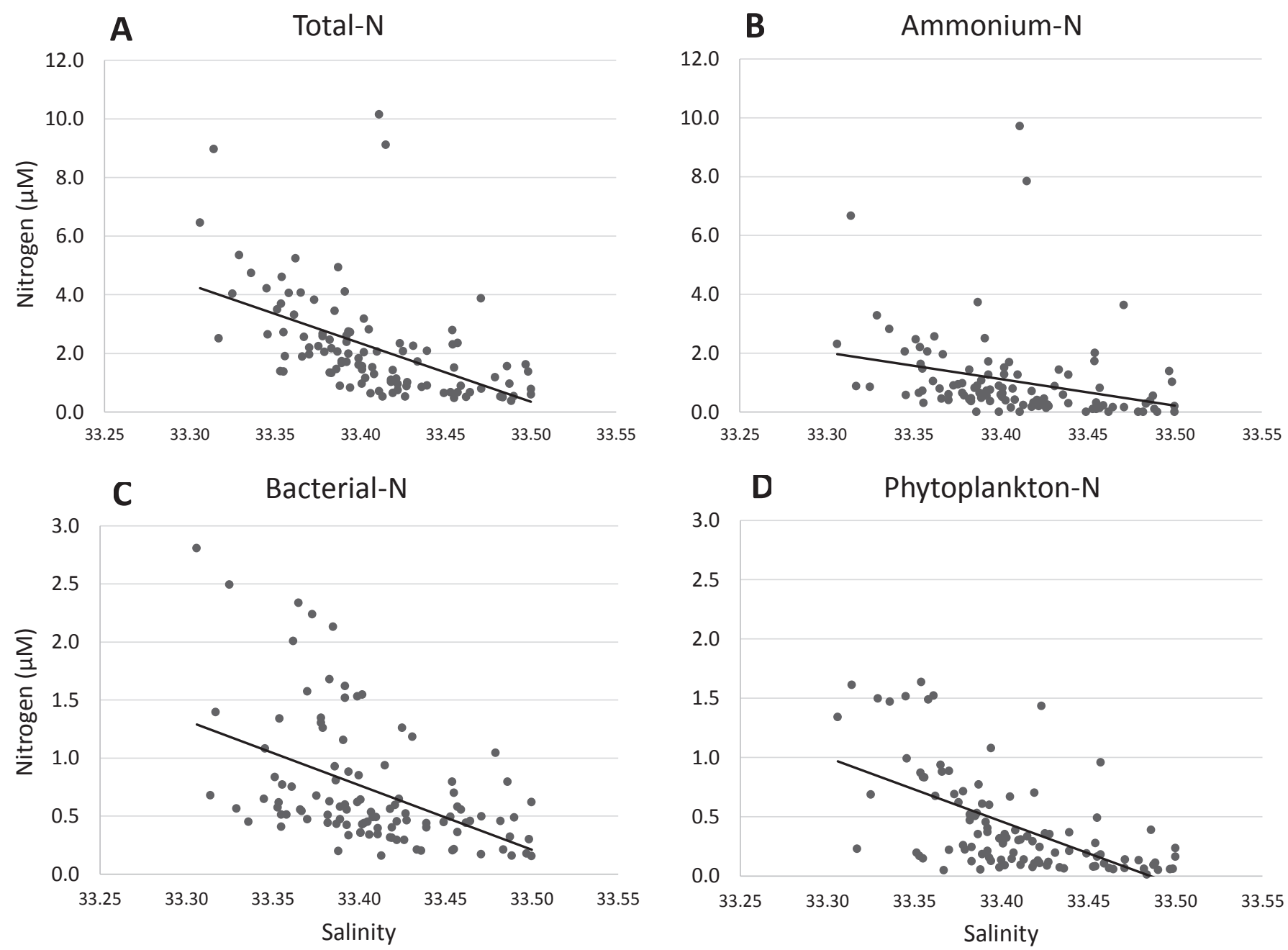

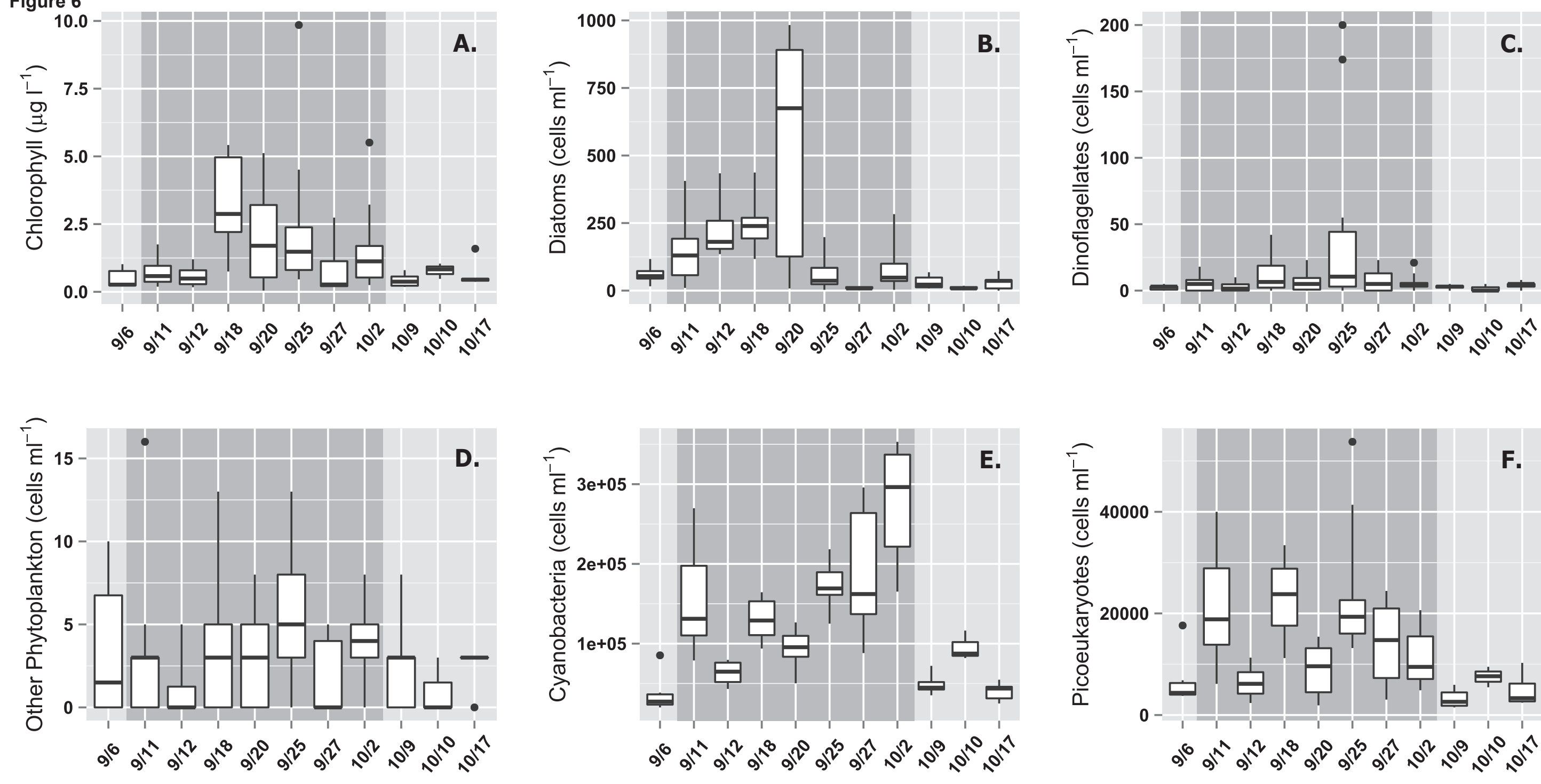

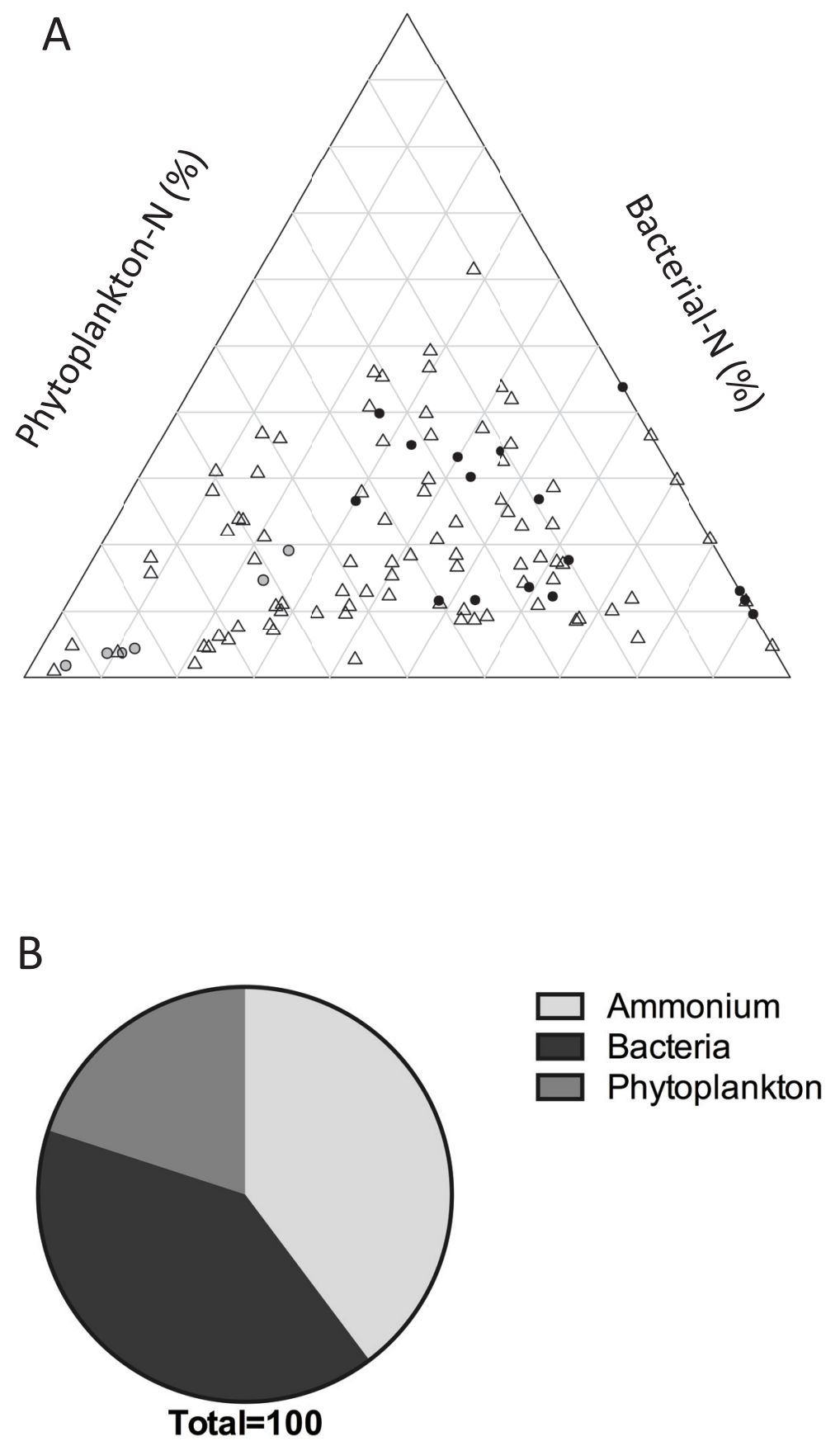
Nutrients in wastewater effluent result in increased bacterial biomass, but phytoplankton response is muted

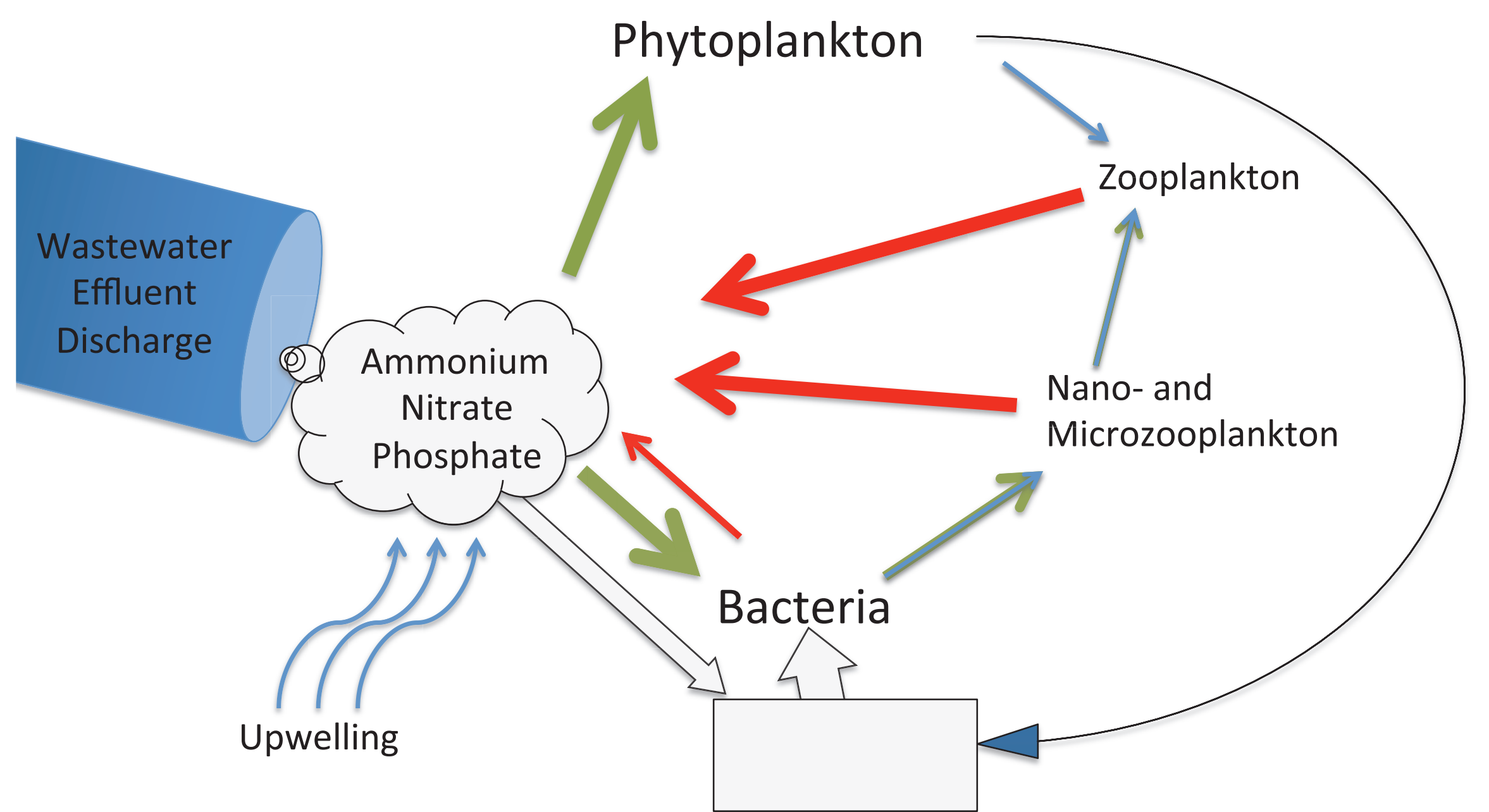

Nutrient assimilation into particulate matter. Nutrient remineralization. 